23

\title{
RELATIVE SEA-LEVEL CHANGE IN CONNECTICUT (USA) DURING THE LAST 2200
}

\section{YEARS}

Andrew C. Kemp ${ }^{1 *}$, Andrea D. Hawkes ${ }^{2}$, Jeffrey P. Donnelly ${ }^{3}$, Christopher H. Vane ${ }^{4}$, Benjamin P. Horton $^{5,6,7}$, Troy D. Hill ${ }^{8}$, Shimon C. Anisfeld ${ }^{8}$, Andrew C. Parnell ${ }^{9}$, and Niamh Cahill ${ }^{9}$

(1)

1. Department of Earth and Ocean Sciences, Tufts University, Medford, MA 02155, USA

2. Department of Geography and Geology, University of North Carolina Wilmington, Wilmington, NC 28403, USA

(2)

3. Department of Geology and Geophysics, Woods Hole Oceanographic Institution, Woods Hole, MA 02543. USA
4. British Geological Survey, Center for Environmental Geochemistry, Keyworth, Nottingham, NG12 5GG, UK

5. Sea Level Research, Department of Marine and Coastal Sciences, Rutgers University, New Brunswick, NJ 08901, USA

6. Institute of Earth, Ocean and Atmospheric Sciences, Rutgers University, New Brunswick, NJ 08901, USA

7. Earth Observatory of Singapore and Asian School of the Environment, Nanyang Technological University, 639798, Singapore

8. School of Forestry and Environmental Studies, Yale University, New Haven, CT 06511, USA

9. School of Mathematical Sciences (Statistics), Complex Adaptive Systems Laboratory, University College Dublin, Dublin 4, Ireland

$24 *$ Corresponding author. andrew.kemp@tufts.edu; 6176270869 
26 We produced a relative sea-level (RSL) reconstruction from Connecticut (USA) spanning the last $\sim 2200$

27 years that is free from the influence of sediment compaction. The reconstruction used a suite of vertically-

28 and laterally-ordered sediment samples $\leq 2 \mathrm{~cm}$ above bedrock that were collected by excavating a trench

29 along an evenly-sloped bedrock surface. Paleomarsh elevation was reconstructed using a regional-scale

30 transfer function trained on the modern distribution of foraminifera on Long Island Sound salt marshes

31 and supported by bulk-sediment $\delta^{13} \mathrm{C}$ measurements. The history of sediment accumulation was estimated

32 using an age-elevation model constrained by radiocarbon dates and recognition of pollution horizons of

33 known age. The RSL reconstruction was combined with regional tide-gauge measurements spanning the

34 last $\sim 150$ years before being quantitatively analyzed using an error-in-variables integrated Gaussian

35 process model to identify sea-level trends with formal and appropriate treatment of uncertainty and the temporal distribution of data. RSL rise was stable $(\sim 1 \mathrm{~mm} / \mathrm{yr})$ from $\sim 200 \mathrm{BCE}$ to $\sim 1000 \mathrm{CE}$, slowed to a

37 minimum rate of rise $(0.41 \mathrm{~mm} / \mathrm{yr})$ at $\sim 1400 \mathrm{CE}$, and then accelerated continuously to reach a current rate of $3.2 \mathrm{~mm} / \mathrm{yr}$, which is the fastest, century-scale rate of the last 2200 years. Change point analysis identified that modern rates of rise in Connecticut began at 1850-1886 CE. This timing is synchronous with changes recorded at other sites on the U.S. Atlantic coast and is likely the local expression of a

41 global sea-level change. Earlier sea-level trends show coherence north of Cape Hatteras that are

42 contrasted with southern sites. This pattern may represent centennial-scale variability in the position 43 and/or strength of the Gulf Stream. Comparison of the new record to three existing and reanalyzed RSL

44 reconstructions from the same site developed using sediment cores indicates that compaction is unlikely

45 to significantly distort RSL reconstructions produced from shallow ( 2-3 $\mathrm{m}$ thick) sequences of salt46 marsh peat. 
Common Era relative sea-level (RSL) reconstructions characterize natural variability, provide a long-term perspective against which to compare recent trends, and capture multiple phases of climate and sea-level behavior for model calibration. Along the U.S. Atlantic coast, these reconstructions are primarily produced from cores of salt-marsh sediment and demonstrate that sea level departed positively and

52 negatively from a stable mean, most noticeably since the onset of historic rates of rise (e.g. Kemp et al., 53 2011).

In high salt-marsh ecosystems on the U.S. Atlantic coast, RSL rise creates accommodation space that is filled by in-situ accumulation of peat. Through this response, salt-marshes preserve their elevation in the tidal frame and the salt-marsh surface tracks rising RSL (e.g. Bloom, 1964; Redfield and Rubin, 1962).

58 Consequently, sequences of high salt-marsh peat are valuable archives from which RSL is reconstructed

59 using proxies for tidal elevation (termed sea-level indicators) and a dated history of sediment accumulation. Foraminifera and plants are sea-level indicators because their distribution on modern salt marshes reflects the varied preferences and tolerances of species to inundation, which is primarily a

62 function of tidal elevation (e.g. Scott and Medioli, 1978). Sequences of salt-marsh sediment are usually recovered as a single core that is processed to provide vertically-ordered samples for reconstructing the

64 tidal elevation at which each sample was originally deposited (termed paleomarsh elevation, PME). A

65 limitation of this approach is that thickening of the sequence as sediment accumulates may cause compaction of underlying material and post-depositional lowering of samples, resulting in an

67 overestimation of the amount and rate of RSL rise (Bloom, 1964; Brain et al., 2012). RSL can also be 68 reconstructed from discrete basal samples that minimize the influence of compaction, but do not provide a 69 continuous record of Common Era RSL change (e.g. Redfield and Rubin, 1962). In Connecticut (and 70 similar regions) it is possible to produce a continuous and basal RSL reconstruction using salt-marsh 
71 sediment that accumulated on top of incompressible bedrock or glacial erratics. Ice retreat from the

72 modern Connecticut coast by $\sim 18,000$ years before present (Balco et al., 2009) exposed bedrock that was

73 later transgressed by salt-marshes because Common Era RSL rose due to ongoing glacio-isostatic

74 adjustment (GIA; e.g. Engelhart et al., 2011). The salt-marsh sediment deposited in contact with bedrock

75 did not experience post-depositional lowering and preserves a compaction-free history of RSL change

76 (Donnelly et al., 2004; Nydick et al., 1995).

77

78 We reconstruct RSL change during the last 2200 years in Connecticut from salt-marsh sediment in direct

79 contact with bedrock to answer two questions: (i) did persistent sea-level trends occur in Connecticut

80 during the Common Era? and (ii) does sediment compaction materially alter patterns of RSL change

81 reconstructed from cores of salt-marsh sediment? Samples from the sediment-bedrock contact were

82 recovered by excavating a trench along the downward slope of a granite outcrop. Foraminifera and bulk

83 sediment $\delta^{13} \mathrm{C}$ values were used as sea-level indicators and sediment accumulation was dated using

84 radiocarbon and regional pollution markers. The resulting RSL record was combined with instrumental

85 measurements to identify positive and negative Common Era sea-level trends in Connecticut. Comparison

86 with other RSL reconstructions from East River Marsh (Nydick et al., 1995) indicates that stratigraphies

87 with intercalated peats are susceptible to compaction, but this compaction does not materially distort

88 reconstructed RSL trends.

2. Study Site

91 East River Marsh (Figure 1) is typical of salt marshes in the northeastern United States (e.g. van de

92 Plassche, 1991). Low-salt marsh environments are vegetated by Spartina alterniflora (tall form) and

93 characterized by muddy sediment. This laterally-narrow floral zone exists between mean tide level (MTL)

94 and mean high water (MHW). The high salt-marsh platform is found between MHW and mean higher 
high water (MHHW). It is vegetated by a mixed meadow of the $\mathrm{C}_{4}$ plants Spartina patens, Distichlis spicata, and Spartina alterniflora (short form) and comprises most of the salt marsh by area. The

97 transition between salt-marsh and freshwater ecosystems occurs between MHHW and highest astronomical tide (HAT). This zone is vegetated by the $\mathrm{C}_{3}$ plants Phragmites australis and Iva fructescens at East River Marsh, but may also be characterized by sedges (e.g. Schoenoplectus americanus). The great diurnal tidal range at the site (mean lower low water, MLLW to MHHW) was estimated as $1.73 \mathrm{~m}$ using the NOAA vertical datum transformation tool for coastal regions (VDatum), compared to $1.74 \mathrm{~m}$ measured by the NOAA tide gauge in Guilford Harbor ( $1.5 \mathrm{~km}$ away; Figure $1 \mathrm{~b})$.

\section{Materials and Methods}

\subsection{Site selection and trench sampling}

East River Marsh was selected because granite bedrock outcrops above the salt-marsh surface and salt-marsh sediment is in direct contact with bedrock. We selected a location where the bedrock sloped evenly at $\sim 30^{\circ}$ to a depth of $\sim 2.4 \mathrm{~m}$ below the modern marsh surface (Figure 2a). Assuming that GIA caused $\sim 1.0$ mm/yr of Common Era RSL rise in southern Connecticut (e.g. Donnelly et al., 2004;

Engelhart et al., 2009; Peltier, 1996), we anticipated that the selected location would provide a continuous

111 sequence of compaction-free sediment spanning the entire Common Era. A trench was excavated to

112 expose the bedrock-sediment contact (Figure 2). The basal sediment was segmented at slight changes in

113 bedrock slope and recovered as a series of adjacent blocks. Sample elevations were measured by leveling

114 the four corners of each block in contact with bedrock to a temporary benchmark, the elevation of which

115 was established (relative to NAVD88) by real time kinematic satellite navigation. Each block was

116 wrapped in plastic, labeled to preserve its original orientation, and refrigerated. The blocks were

117 subsequently cut into $1-\mathrm{cm}$ thick basal samples representing $1-\mathrm{cm}$ increments of elevation (Figure $2 \mathrm{~b}$ ).

118 This approach created a suite of vertically- and laterally-ordered sediment samples that were deposited $\leq 2$ 
$\mathrm{cm}$ above the bedrock surface. The position of each sampled is expressed in a two-dimensional (depth and

120 distance) co-ordinate system where the top of the trench (1.01 $\mathrm{m}$ above MTL) is the origin. Sample

121 positions discussed in the text and presented on figures use this reference frame. All subsequent analyses

122 (radiocarbon and pollution dating, foraminiferal counts, and $\delta^{13} \mathrm{C}$ measurements) were performed on this

123 set of samples that we consider to be free from the effects of sediment compaction. In most cases a thin

$124(<2 \mathrm{~mm})$ mat of fine roots was removed from the bottom of each sample and discarded after inspection.

125 This mat formed by the growth of roots from younger plants at the surface along the sediment-bedrock

126 interface.

\subsection{Modern foraminifera}

129 At 12 salt marshes we established transects across the prevailing elevation and environmental gradient to 130 describe the modern distribution of foraminifera (Figure 1a). These sites represent the spatial, ecological, 131 and geomorphological range of salt marshes on the north coast of Long Island Sound and complement the 132 distribution of existing modern datasets. At East River Marsh we sampled two parallel transects (Figure 133 1c) that included highest-marsh environments where the shallow, amorphous sediment overlying bedrock 134 is analogous to the basal sediment that accumulated in the trench. Similar highest salt-marsh sediments and environments were also sampled at other sites. We combined the new dataset of modern foraminifera

136 with those summarized by Wright et al. (2011) to produce a regional training set consisting of 254

137 modern foraminifera samples from 16 sites on the north coast of Long Island Sound (Figure 1) including 13892 samples from four Connecticut sites that were reported in published literature (Edwards et al., 2004; 139 Gehrels and van de Plassche, 1999). The new modern foraminifera data are presented in the supporting 140 appendix. 
143 A weighted-averaging transfer function with inverse deshrinking (WA-inv) was developed to quantify the

144 relationship between modern foraminifera and tidal elevation from the expanded modern dataset. Model

145 comparisons are presented and discussed in the Supporting Material. To combine data from sites with

146 different tidal ranges into a regional training set, we applied a standardized water level index (e.g. Horton,

147 1999).

$\mathrm{SWLI}=\frac{\text { Alt }_{\mathrm{ab}}}{\mathrm{MHHW}_{\mathrm{b}}-\mathrm{MTL}_{\mathrm{b}}} * 100$

148 where $A l t_{a b}$ is the measured altitude of sample $a$ collected at site $b$ (expressed relative to MTL) and

$149 M H H W_{b}-M T L_{b}$ are tidal datums at site $b$. The highest occurrence of foraminifera (Wright et al., 2011) was

150 not used as a SWLI datum because at some sites foraminifera were present in all surface samples meaning

151 that their highest occurrence was not captured. The WA-inv transfer function was applied to the trench

152 samples from which foraminifera were enumerated to reconstruct. A sample-specific $(\sim 1 \sigma)$ uncertainty

153 (Juggins and Birks, 2012) was calculated for each PME estimate using bootstrapping ( $n=1000)$. Transfer

154 function output was in SWLI units and converted to MTL using the modern tidal prism at East River

155 Marsh. The ecological plausibility of PME reconstructions was judged by measuring the dissimilarity

156 between trench samples and their closest analogue in the modern training set using the Bray-Curtis

157 distance metric. If the distance exceeded the $20^{\text {th }}$ percentile of distance calculated among all pairings of

158 modern samples, the trench sample was classified as lacking a modern analogue and was excluded from

159 the RSL reconstruction.

$3.4 \delta^{13}$ C measurement

162 In the northeastern U.S. and maritime Canada, in-situ deposition of plant material is the primary source of 163 salt-marsh organic material (e.g. Chmura and Aharon, 1995). Therefore the ratio of stable carbon isotopes

$164\left(\delta^{13} \mathrm{C}\right)$ in bulk sediment reflects the dominant vegetation community at the time of deposition (e.g. 
Middleburg et al., 1997) and can be used as a sea-level indicator if the plant community has a systematic relationship to tidal elevations (Johnson et al., 2007; Kemp et al., 2013a). Bulk sediment $\delta^{13} \mathrm{C}$ values were measured using the methods and instruments described in Kemp et al. (2013a).

\subsection{Trench chronology}

The timing of basal sediment deposition was constrained by radiocarbon dating of plant macrofossils in growth position and small pieces of wood that we interpreted as having been deposited on a paleo-marsh surface (Table 1). After separation from the sediment matrix, 15 radiocarbon samples were cleaned under a microscope to remove in-growing younger roots and older adhered sediment, oven dried $\left(45^{\circ} \mathrm{C}\right)$, and submitted to National Ocean Science Accelerator Mass Spectrometry (NOSAMS) facility for dating. All samples underwent standard acid-base-acid pretreatment at NOSAMS.

Recognition of pollution horizons of known age from trends in concentrations of copper, lead, mercury, ${ }^{137} \mathrm{Cs}$, and ratios of stable lead isotopes $\left({ }^{206} \mathrm{~Pb}:{ }^{207} \mathrm{~Pb}\right)$ established the timing of recent sediment deposition, because the utility of radiocarbon for material younger than $\sim 350$ years is hindered by a plateau in the calibration curve. Copper, lead, and ${ }^{206} \mathrm{~Pb}:{ }^{207} \mathrm{~Pb}$ trends and their stratigraphic position were matched to features of historic production and consumption, which were assumed to approximate the timing and relative magnitude of atmospheric emissions and deposition (Gobeil et al., 2013; Kemp et al., 2012a; Lima et al., 2005). Trends in mercury concentration were matched to those reported at nearby sites in cores of independently dated salt-marsh sediment (e.g. Varekamp et al., 2003). Peak ${ }^{137}$ Cs activity was assigned an age of $1963 \mathrm{CE}$ reflecting the peak in above ground testing of nuclear weapons. Elemental concentrations and $\mathrm{Pb}$ isotopes were measured using the methods and instruments described in Vane et al. (2011) and Kemp et al. (2012a). Mercury measurements were made on a Milestone DMA-80 direct mercury analyzer at Yale University. Activity of ${ }^{137} \mathrm{Cs}$ was measured by gamma spectroscopy at Yale University using standard methods. 
191 All age estimates were assimilated into a single age-elevation model using Bchron, which produces 192 posterior estimates of sample age using Markov Chain Monte Carlo simulation, each of which is 193 equi-probable (Haslett and Parnell, 2008; Parnell et al., 2008). The resulting suite of chronologies is 194 summarized by Bchron to estimate sample ages with a 95\% uncertainty interval. Radiocarbon ages were 195 specified as having a thickness of $2 \mathrm{~cm}$ to recognize that plant macrofossils grow slightly below the 196 surface on which contemporary foraminifera lived. This approach acknowledges uncertainty in contrast to 197 adjusting the depths of radiocarbon dates by a fixed amount. Chrono horizons established from ${ }^{137}$ Cs and 198 pollution markers were treated as having uniform probability distributions.

\subsection{Relative sea-level trends}

201

202

203

204 205

RSL was reconstructed by subtracting PME from measured sample elevation, where both quantities were expressed relative to MTL. When combined with age estimates from the age-elevation model, the RSL reconstruction is characterized by data points that are unevenly distributed through time and have a unique combination of vertical and temporal uncertainty. The RSL reconstruction was combined with a regional tide-gauge record from Long Island Sound. Annual tide-gauge measurements from The Battery, Willets Point, Port Jefferson, Bridgeport, New London, Montauk, and Newport (Figure 1a) were averaged to produce a single instrumental RSL record with a vertical uncertainty estimated by calculating the annual standard deviation across six of the tide gauges for 1950-2013 CE (the Port Jefferson gauge ceased recording in $1990 \mathrm{CE}$ and therefore was not included in this estimate of uncertainty). The average of these annual standard deviations was $0.011 \mathrm{~m}$ and an uncertainty of $\pm 0.022 \mathrm{~m}$ was applied to each annual data point along with an age uncertainty of \pm 0.5 years. 
213 Quantitative RSL trends with formal uncertainties were estimated by applying an error-in-variables

214 integrated Gaussian process (EIV-IGP) model (Cahill et al., 2015) to the combined RSL dataset of proxy

215 reconstructions and tide-gauge measurements. The EIV component (Dey et al., 2000) accounts for error

216 in the explanatory variable (sample age), which is assumed to be fixed and known in standard regression.

217 Since sample ages are uncertain, the EIV approach is appropriate and necessary. The Gaussian process

218 component (Rasmussen and Williams, 2005) is a practical approach to modelling non-linear time series

219 data such as RSL reconstructions. We model the rate of sea-level change (i.e. the first derivative) and

220 subsequently integrate it to form an integrated Gaussian process (IGP; Holsclaw et al., 2013), which aims

221 to match RSL. The Gaussian process has a prior distribution specified by a mean function (here set to a

222 constant) and a covariance function that determines the smoothness of the reconstructions. In this

223 Bayesian model, the posterior rate and covariance function are learnt from the data. The IGP component

224 is embedded within the EIV framework to account for age uncertainties, vertical uncertainties, and the

225 covariance that is introduced by removing a rate of GIA. The model does not account for uncertainty in

226 the rate of GIA, which must be specified as an input.

228 The covariance function of the Gaussian process prior placed on the rate of sea-level is structured such 229 that the correlation between two individual data points depends on the time difference between them 230 rather than their absolute position in time. For example, it assumes that the magnitude of the change in 231 rate between two data points at $1880 \mathrm{CE}$ and $1890 \mathrm{CE}$ will be approximately the same as two data points 232 at $1980 \mathrm{CE}$ and $1990 \mathrm{CE}$. Whilst the integrated process (representing sea level itself) can display more 233 complex behavior, previous work showed that this global smoothness assumption is robust to 234 mis-specification (Cahill et al., 2015), especially once we account for the uncertainties in both age and 235 elevation. This approach captures the continuous and dynamic evolution of RSL change with full 236 consideration of many sources of uncertainty. Modeled uncertainties are smaller than those of the original 237 reconstruction because the EIV-IGP model exploits the probability distribution (vertical and temporal) 
within a single data point and the relationship among temporally-ordered data points to produce probabilistic estimates of sea level and the rate of sea-level change at any point in time. We also used

240 change point analysis to provide a best estimate of when modern rates of sea-level rise began following

241 the approach described in Kemp et al. (2013a).

\section{Results}

\subsection{Trench stratigraphy, foraminifera, and $\delta^{13} \mathrm{C}$}

245 The excavated trench was $\sim 8 \mathrm{~m}$ long and reached a maximum depth of $\sim 2.4 \mathrm{~m}$. The basal sediment 246 (approximately 3-20 cm thick) in contact with bedrock was uniformly a black, amorphous organic unit 247 with angular, sand-sized grains eroded from the underlying granite and sparse plant macrofossils (Figure

248 2). This unit is analogous to surface sediment from the margin between highest salt-marsh environments 249 and bedrock islands at East River Marsh, including the upper reaches of the sampled trench. The 250 overlying sediment exposed in the trench included salt-marsh peat with abundant, in-situ remains of 251 Distichlis spicata and Spartina patens, as well as a grey, peaty-mud unit.

253 Foraminifera were enumerated from 121 evenly-spaced trench samples to reconstruct PME (Figure 3a).

254 From $242 \mathrm{~cm}$ to $178 \mathrm{~cm}$ below the trench top, the most common species of foraminifera were 255 Trochammina inflata and Siphotrochammina lobata (average 45\% of individuals). From $176 \mathrm{~cm}$ to 31 $\mathrm{cm}$, Jadammina macrescens was the most abundant species (average 65\% of individuals). The uppermost

$25730 \mathrm{~cm}$ was characterized by increased abundances of Haplophragmoides spp. (average $34 \%$ of 258 individuals) with Trochammina inflata and Siphotrochammina lobata (average $41 \%$ of individuals).

259 Between $108 \mathrm{~cm}$ and $124 \mathrm{~cm}$ foraminifera were sparse ( $<5$ individuals) or absent. Intervals of low test 
abundance could be the result of test dissolution or low concentrations of tests as a consequence of low

261 reproduction rates, high sedimentation rates, or patchy distributions.

263 To identify samples lacking a modern analogue, dissimilarity between populations of foraminifera

264 preserved in trench samples and their modern counterparts was measured using the Bray-Curtis metric

265 (Figure 3b). The closest modern analogues for trench samples were drawn from six different sites, which

266 likely reflects sub-regional spatial variability in the composition of high-marsh assemblages as observed

267 on modern salt marshes in Connecticut and elsewhere (e.g. Kemp et al., 2013b; Wright et al., 2011). The

268 distance between nine trench samples and their closest modern analogue exceeded the $20^{\text {th }}$ percentile of

269 dissimilarity measured among all pairings of modern samples and these samples were excluded from

270 further analysis. Eight of the excluded samples $(36-66 \mathrm{~cm})$ were characterized by high abundances of

271 Jadammina macrescens (>68\%) and the presence of Miliammina petila (4-21\%; average 14\%). The

272 modern training set includes samples with comparable abundances of Jadammina macrescens (up to

$273100 \%$ ) and Miliammina petila (up to 10\%, excluding a single sample of 63\% from East River Marsh).

274 However, the maximum abundance of Jadammina macrescens in modern samples containing at least $1 \%$

275 Miliammina petila was 34\%. The unusual co-occurrence of these two species caused the trench samples

276 to lack a modern analogue.

278 Application of the WA-inv transfer function to the remaining 112 samples produced PME reconstructions

279 with sample-specific uncertainties that ranged from $\pm 0.158 \mathrm{~m}$ to $\pm 0.165 \mathrm{~m}$, equivalent to approximately

$280 \pm 10 \%$ of great diurnal range at East River Marsh (Figure 3c). These results show that the samples were

281 deposited between MHHW and HAT at the leading edge of a RSL transgression and are supported by

282 bulk sediment $\delta^{13} \mathrm{C}$ values of $-25.1 \%$ to $-18.9 \%$ indicating significant input from $\mathrm{C}_{3}$ vegetation (Figure

$2833 \mathrm{~d}$ ). Along the U.S. mid-Atlantic and northeastern coasts, these $\delta^{13} \mathrm{C}$ values coupled with the presence of 

the highest occurrence of foraminifera (Johnson et al., 2007; Kemp et al., 2013a; Middleburg et al., 1997). The samples where foraminifera were sparse or absent probably formed in an environment between

287 MHW and HAT (Engelhart et al., 2011; van de Plassche, 1991) as evidenced by $\delta^{13} \mathrm{C}$ values between 288 those typical of $\mathrm{C}_{3}$ and $\mathrm{C}_{4}$ plants (coupled with sediment texture that is the same throughout the basal 289 section of the trench). Measured $\delta^{13} \mathrm{C}$ values were not used to constrain PME reconstructions because 290 most samples had values between those of $\mathrm{C}_{3}$ and $\mathrm{C}_{4}$ vegetation. When salt-marsh sediment is sampled 291 with a core the location of the PME reconstruction is static and the change from highest salt-marsh peat to 292 high salt-marsh peat that occurs because of RSL rise happens only once. Deeper samples in the core have $293 \delta^{13} \mathrm{C}$ values that are typical of the $\mathrm{C}_{3}$ plants that occupy elevations above MHHW. Samples further up the 294 core have $\delta^{13} \mathrm{C}$ values that are typical of the $\mathrm{C}_{3}$ plants that occupy elevations below MHHW (see for example Kemp et al., 2012b). In contrast, the sediment used in the trench reconstruction tracks the lateral and vertical RSL transgression, which is reflected in the bulk sediment samples having intermediate $\delta^{13} \mathrm{C}$ 297 values because all of the samples were likely deposited close to MHHW. Therefore it was not possible to use $\delta^{13} \mathrm{C}$ values to reduce reconstruction error as they were elsewhere (Kemp et al., 2013a).

\subsection{Trench chronology}

301 Fifteen radiocarbon dates demonstrate that the trench spans the interval since 200 BCE (Table 1). The 302 uppermost part of the core was dated by identifying pollution chronohorizons that were related to historic 303 events such as above-ground testing of nuclear weapons and trends in national and regional (Upper 304 Mississippi Valley) industrial production (Figure 4). We assumed that industrial emissions were 305 transported to East River Marsh by prevailing wind patterns and deposited on the salt-marsh surface 306 within a few years and without further isotopic fractionation (e.g. Gobeil et al., 2013). Trends rather than 307 absolute values were the basis for recognizing chronohorizons because emissions rates per unit of 
production changed through time. The accuracy of this approach was demonstrated in studies that validated chronologies established from pollution markers against independent age constraints in eastern

310 North America such as ${ }^{210} \mathrm{~Pb}$ in salt-marsh sediment (Gobeil et al., 2013; Kemp et al., 2012a) and varved

311 lake sediments (Lima et al., 2005). Discrepancies among sample ages estimated from different pollution

312 markers (Figure 4) may arise due to local-scale variability in the trends and timing of pollution or from

313 chemical mobility in the sediment profile. Bchron produces probabilistic age estimates and negates the

314 need to choose among conflicting pollution markers by identifying chronologies that are more and less

315 likely to be accurate rather than discarding outliers. The Bchron age-elevation model estimated the age of 316 each trench sample with an average $95 \%$ credible interval of approximately \pm 50 years (Figure 5). In the 317 upper part of the core, this credible interval overlaps with the individual uncertainties of 12 of the 14 318 pollution markers.

\subsection{Relative sea-level change}

321 Annual tide-gauge measurements from seven locations in and near Long Island Sound (Figure 1) are 322 highly correlated, indicating that the long-term trends and decadal variability they recorded were regional 323 in scale and justifying the creation of an averaged record (although The Battery was the only instrument 324 in operation for the period between 1856 CE and 1930 CE; Figure 6a). The East River Marsh RSL 325 reconstruction is comprised of 112 datapoints, each of which has a unique combination of vertical and 326 temporal uncertainty (Figure 6b; data provided in supporting appendix). The averaged tide-gauge record 327 lies within the uncertainty of the reconstruction and the two datasets were combined prior to analysis. 328 Application of the EIV-IGP model (Figure 6c) shows that RSL rose at $\sim 1 \mathrm{~mm} / \mathrm{yr}$ from $\sim 200 \mathrm{BCE}$ to $329 \sim 1000 \mathrm{CE}$. The rate of RSL rise subsequently decelerated to a minimum of $0.41 \mathrm{~mm} / \mathrm{yr}(0.17-0.63 \mathrm{~mm} / \mathrm{yr}$; $33095 \%$ credible interval) at $\sim 1400 \mathrm{CE}$. The $95 \%$ credible interval of the model predictions at $\sim 1600-1800$ 331 CE lie below the mid-point of RSL reconstructions, but within their uncertainty (Figure 6c). RSL rise 
then accelerated continuously to a current rate of $3.2 \mathrm{~mm} / \mathrm{yr}(2.93-3.49 \mathrm{~mm} / \mathrm{yr}$; $95 \%$ credible interval), which is the fastest rate of century-scale rise in at least the last 2200 years (Figure 6d). Change-point analysis performed on the combined proxy and instrumental dataset showed a significant increase in the rate of RSL rise at $1850-1886 \mathrm{CE}$ (95\% credible interval).

\section{Discussion}

\subsection{Relative sea-level change and sediment compaction at East River Marsh}

Previous research in Connecticut established the framework for producing continuous RSL reconstructions using single cores of salt-marsh sediment (e.g. Thomas and Varekamp, 1991; van de

341 Plassche et al., 1998; Varekamp et al., 1992). RSL change during the last $~ 1500$ years at East River

342 Marsh and West River Marsh was reconstructed by Nydick et al. (1995) using three cores of high

343 salt-marsh sediment (GA, GD, and GK; Figure 1). Each core was dated using five radiocarbon ages and 344 by identifying the onset of anthropogenic pollution (1877 CE \pm 15 years) from down-core copper and zinc 345 concentrations. We investigated the influence of compaction on sequences of salt-marsh sediment by 346 comparing the compaction-free RSL reconstruction from the trench to those generated from cores. We 347 assumed that any differences among the four RSL reconstructions were principally the result of sediment 348 compaction because other local factors such as tidal-range change should be consistent among records in 349 such close proximity to one another. To ensure that all the reconstructions could be meaningfully 350 compared, we reanalyzed cores GA, GD, and GK by applying our Long Island Sound transfer function to 351 the reported assemblages of foraminifera and developing a Bchron age-depth model using the reported 352 radiocarbon ages and position of the pollution marker as input. We estimated core-top elevations using 353 the transfer function reconstruction for the surface sample in each core. This reanalysis generated three 354 RSL reconstructions to compare with the trench reconstruction (Figure 7). 
The RSL reconstruction from the trench lies within the uncertainty of the GK record indicating a lack of

357 detectable compaction. In contrast, the trench reconstruction is above (and outside of) the uncertainty

358 bounds of the GA reconstruction prior to $\sim 1300 \mathrm{CE}$ and is higher than the RSL reconstruction from GD

359 prior to 1200 CE. Cores GA and GD include units of salt-marsh peat that are intercalated by grey, clayey

360 peat (Figure 7). Empirical data (e.g. Bloom, 1964) and modeling studies (Brain et al., 2012) show that

361 intercalated peat is susceptible to compaction. In contrast, continuous sequences of high salt-marsh peat

362 (such as those used elsewhere along the U.S. Atlantic coast; Figure 8) undergo little compaction (Brain et

363 al., 2015). The pattern of increasing difference with depth and age between RSL reconstructed from the

364 trench and cores GA and GD is suggestive of post-depositional lowering of the core samples and indicates

365 that sediment compaction may distort RSL reconstructions generated from stratigraphies that include

366 intercalated salt-marsh peats. This distortion is greatest $(0.42 \mathrm{~m})$ at $\sim 830 \mathrm{CE}$ in core GA, but with

367 consideration of uncertainties in the EIV-IGP models it could range from $0.13 \mathrm{~m}$ to $0.72 \mathrm{~m}$. However,

368 there is no detectable compaction in core GK despite it being a longer-duration record produced from a

369 sedimentary sequence that also includes intercalated peat. It is likely that the accuracy of the lowest

370 radiocarbon date in core GA rather than compaction is the primary reason for the difference to the trench

371 reconstruction. These comparisons suggest that compaction did not materially distort the reconstructions

372 and that single cores of salt-marsh sediment can be representative of the principal RSL trends that

373 occurred at a site if placed in, and supported by, an appropriate stratigraphic framework.

\subsection{Sea-level change on the U.S. Atlantic coast}

376 During most of the Common Era, spatially-variable GIA was the primary driver of RSL change along the

377 U.S. Atlantic coast. GIA includes a component of vertical land motion driven by the collapse of the

378 Laurentide Ice Sheet's proglacial forebulge and also a geoid component resulting from the redistribution

379 of mass as mantle material returns to regions beneath formerly glaciated areas. Predictions from Earth-ice 
models (e.g. Peltier, 1996) and RSL reconstructions (e.g. Engelhart et al., 2009) show that the rate of

381 Common Era and ongoing GIA varies systematically with distance from the former center of the

382 Laurentide Ice Sheet. The ICE6G-C-VM5a model (Peltier et al., 2014) predicts a current GIA-driven RSL

383 rise of $\sim 1.0 \mathrm{~mm} / \mathrm{yr}$ at East River Marsh. Similarly, at Barn Island, Connecticut (Figure 1a), a

384 compaction-free RSL reconstruction spanning the period $~ 1300-1850$ CE estimated the background rate

385 of Common Era RSL rise to be $1.0 \pm 0.2 \mathrm{~mm} / \mathrm{yr}$ (Donnelly et al., 2004). Under the assumption that RSL

386 change over this period was driven exclusively by GIA and any other process(es) causing vertical land

387 motion (such as dynamic topography; e.g. Rowley et al., 2013), this rate is an estimate of the ongoing

388 contribution of land-level change to reconstructed RSL change during the Common Era. To compare RSL

389 reconstructions from different sites along the U.S. Atlantic coast and to identify climate-driven sea-level

390 trends during the Common Era, we removed $0.9 \mathrm{~mm} / \mathrm{yr}$ from the new Connecticut RSL reconstruction

391 and used the EIV-IGP model to account for the covariance of age and vertical uncertainties introduced by

392 this adjustment (Cahill et al., 2015). We assumed a constant rate of GIA over the 2200 year duration of

393 the reconstruction because this period is short relative to the adjustment time of the solid Earth to

394 deglaciation. This analysis shows positive and negative departures from stable sea level (Figure 8a).

395 There was a slight sea-level rise of $\sim 0.18 \mathrm{~mm} / \mathrm{yr}$ at approximately $600-1000 \mathrm{CE}$. The rate of sea-level

396 change fell to a minimum of $-0.42 \mathrm{~mm} / \mathrm{yr}$ at $\sim 1400 \mathrm{CE}(-0.22$ to $-0.62 \mathrm{~mm} / \mathrm{yr} ; 95 \%$ credible interval $)$. The

397 rate of sea-level rise then accelerated continuously until reaching the current rate of $2.38 \mathrm{~mm} / \mathrm{yr}$

$398(2.16-2.62 \mathrm{~mm} / \mathrm{yr} ; 95 \%$ credible interval), which is the fastest, century-scale rate in the past 2200 years.

399 The compaction-free sea-level trend reconstructed at East River Marsh shows broad agreement with

400 reconstructions from other sites in Connecticut including Hammock River Marsh (Thomas and

401 Varekamp, 1991; van de Plassche et al., 1998; Varekamp et al., 1992).

403 To compare the new detrended sea-level reconstruction from Connecticut with others from elsewhere

404 along the U.S. Atlantic coast, we applied the EIV-IGP and change-point models to existing records from 
Change-point analysis shows a sharp and synchronous increase in the rate of sea-level rise that began in the $19^{\text {th }}$ century with a common timing of $1865-1873 \mathrm{CE}$ among the four records (Figure 8). The global tide-gauge compilation of Church and White $(2006,2011)$ covers the period since $1870 \mathrm{CE}$ and they noted that the acceleration of global sea-level rise commenced in the $19^{\text {th }}$ century, with a secondary rate increase at $\sim 1930$ CE. This is supported by a recent reanalysis of the Church and White (2011) dataset, which shows global sea-level rise in excess of GIA at $1880 \mathrm{CE}(>1 \mathrm{~mm} / \mathrm{yr})$ and a continuous acceleration 412 to reach $\sim 2 \mathrm{~mm} / \mathrm{yr}$ at $2010 \mathrm{CE}$ (Cahill et al., 2015). Similarly, Hay et al. (2015) demonstrated that the rate 413 global mean sea-level was positive and increased throughout the $20^{\text {th }}$ century. These findings indicate that sea-level rise on the U.S. Atlantic coast and globally began prior to 1880 CE. The tide-gauge compilation of Jevrejeva et al. (2008) extends to $1700 \mathrm{CE}$, but prior to $1850 \mathrm{CE}$ is based (out of necessity) only on records from Amsterdam, Liverpool, and Stockholm and therefore may not be representative of

417 global trends. However, application of the change-point model to this record identified two intervals when 418 the rate of sea-level rise increased (Figure 9). The primary change occurred at 1827-1860 CE and there was a secondary increase at 1924-1943 CE. If the Jevrejeva et al. (2008) compilation is taken to represent global sea-level trends, then the difference in timing between the tide-gauge record (1827-1860 CE) and 421 sea-level reconstructions (1865-1873 CE) suggests a short lag time between the onset of global sea-level 422 rise and its detection in salt-marsh sediments along the U.S. Atlantic coast (Figure 9). We contend that 423 sea-level rise on the U.S. Atlantic coast accelerated in the late $19^{\text {th }}$ century in response to global mean 424 sea-level change. The reconstructions record the local to regional-scale expression of this global change 425 caused by increased ocean mass and volume (Church et al., 2013). Departures from the global mean in the 426 amount and rate of sea-level change may occur even after correction for GIA because of the static 427 equilibrium (fingerprint) effect of ice melt (e.g Hay et al., 2014; Mitrovica et al., 2001) and simultaneous 428 contributions from regional-scale processes such as ocean dynamics. The $19^{\text {th }}$ century onset of accelerated 429 sea-level rise contradicts the IPCC AR5, which concluded with high confidence that "rates of sea level 430 rise exceeded the late Holocene background rate after about 1900" (Masson-Delmonte et al., 2013). 
432 Two salt-marsh reconstructions from the United Kingdom did not definitively detect this acceleration 433 (Barlow et al., 2014; Long et al., 2014). This apparent absence is puzzling for two reasons. Firstly, it is 434 present in the Jevrejeva et al. (2008) tide-gauge compilation which relies entirely on instrumental records 435 from northern Europe (including the United Kingdom) prior to 1850 CE (Figure 9). Secondly, analysis of 436 long tide-gauge records from the United Kingdom shows that $20^{\text {th }}$ century rates of sea-level rise (e.g. 437 Woodworth et al., 2009) exceeded long-term, GIA-driven regional trends (e.g. Shennan and Horton, 438 2002), indicating that the rate of sea-level rise increased (e.g. Shennan and Woodworth, 1992). A muted 439 regional response to global mean sea-level change in the eastern North Atlantic and/or an exaggerated 440 response to global mean sea-level change in the western North Atlantic could cause sea-level trends to 441 differ across the Atlantic Ocean and for all proxy reconstructions to be accurate recorders of regional 442 trends. In the United Kingdom, the average $20^{\text {th }}$ century difference between GIA-driven background rates 443 and those measured by tide-gauges was $1.4 \pm 0.2 \mathrm{~mm} / \mathrm{yr}$ (Woodworth et al., 2009). In comparison, 444 estimates of global mean sea-level rise include $1.7 \pm 0.2 \mathrm{~mm} / \mathrm{yr}$ during the $20^{\text {th }}$ century (Church and 445 White, 2011) and $1.2 \pm 0.2 \mathrm{~mm} / \mathrm{yr}$ for 1901-1990 CE (Hay et al., 2015). The difference was $\sim 1.9 \mathrm{~mm} / \mathrm{yr}$ 446 in Connecticut, New Jersey, and North Carolina and $\sim 1.5 \mathrm{~mm} / \mathrm{yr}$ in Florida (Figure 8). Sea-level rise in 447 the United Kingdom was similar to global estimates and we propose that large reconstruction 448 uncertainties (approximately $\pm 0.4 \mathrm{~m}$ in Scotland and $\pm 0.3 \mathrm{~m}$ in the Isle of Wight record), and/or the 449 insensitivity of minerogenic European salt marshes to accelerated sea-level change compared to their 450 organogenic equivalents in North America prevented reliable detection of this feature of Common Era 451 sea-level rise.

453 Prior to $1800 \mathrm{CE}$, Common Era sea-level reconstructions support the conclusion of IPCC AR5 that 454 "centennial-scale global mean sea-level variations did not exceed $25 \mathrm{~cm}$ over the past few millennia" 

correction applied, but the timing and direction (positive or negative) of centennial-scale departures from

457 this long term trend are robust (Figure 8). In Connecticut, there was a sea-level rise at $\sim 600-1000 \mathrm{CE}$ with 458 a maximum mean rate of $0.23 \mathrm{~mm} / \mathrm{yr}$ and a sea level fall at $\sim 1200-1700 \mathrm{CE}$ (maximum mean rate of -0.42 $459 \mathrm{~mm} / \mathrm{yr}$ ). In New Jersey, there was a positive departure at $~ 300-900 \mathrm{CE}$ and a negative departure at $460 \sim 1100-1700 \mathrm{CE}$. The slight difference in timings between records could reflect the distribution of 461 radiocarbon dates used to constrain the age-depth models. Similar patterns of change occurred in North 462 Carolina, but they are asynchronous with those in New Jersey and Connecticut because the rise occurs at $463 \sim 1000-1400 \mathrm{CE}$, although there is some overlap in the timing of the fall, which occurs at $\sim 1500-1800 \mathrm{CE}$. 464 There is no meaningful deviation from zero sea-level change in Florida until the onset of modern rates of 465 rise. This pattern suggests that local- to regional-scale processes were the primary drivers of sea-level 466 change along the U.S. Atlantic coast prior to the $19^{\text {th }}$ century.

468 Sediment compaction could cause variability among reconstructions because the records from outside of 469 Connecticut were developed from cores of high salt-marsh peat that varied in thickness from $\sim 1.2 \mathrm{~m}$ in 470 Florida to $4.0 \mathrm{~m}$ in New Jersey. However, the coherence between New Jersey (most susceptible to 471 compaction) and Connecticut (compaction-free) indicates that sediment compaction was not the primary

472 cause of reconstructed spatial sea-level variability. Similarly, a geotechnical model estimated that 473 sediment compaction contributed $<0.03 \mathrm{~m}$ to the $1.4 \mathrm{~m}$ reconstructed RSL rise since $\sim 1000$ CE in North 474 Carolina (Brain et al., 2015). Therefore, it is necessary to seek an alternative mechanism to explain the 475 spatial differences among reconstructions.

477 On the U.S. Atlantic coast, the contrast in sea-level trends north and south of Cape Hatteras on 478 instrumental (Ezer et al., 2013; McCarthy et al., 2015; Yin and Goddard, 2013) and Common Era 
timescales (Kemp et al., 2014) were partially attributed to changes in the strength and/or position of the

480 Gulf Stream. The reconstruction from Connecticut supports this interpretation because of its coherence

481 with New Jersey and their shared dissimilarity to Florida prior to the $19^{\text {th }}$ century. Proxy evidence from

482 the Florida Strait indicates a $\sim 3$ Sv reduction in Gulf Stream strength during the Little Ice Age (at $\sim 1350$ -

$4831750 \mathrm{CE}$; Lund et al., 2006), which modeling studies suggest would cause a 1.5-6 cm sea-level rise north

484 of Cape Hatteras (e.g. Kienert and Rahmstorf, 2012). This ocean dynamic effect could potentially offset

485 sea-level fall from negative changes in ocean mass and volume caused by cooling temperatures. Climate

486 reconstructions indicate that global temperature cooled from a peak of approximately $+0.1^{\circ} \mathrm{C}$ at $\sim 950 \mathrm{CE}$

487 to a minimum of $-0.6^{\circ} \mathrm{C}$ at $\sim 1700 \mathrm{CE}$ compared to the $1850-2006 \mathrm{CE}$ average (Mann et al., 2008),

488 although the timing and magnitude of cooling varied among continents with notable cold periods in North

489 America centered on $~ 1650 \mathrm{CE}$ and $~ 1850 \mathrm{CE}$ (PAGES 2k Consortium, 2013). As temperatures cooled

490 the rate of RSL rise in Connecticut and New Jersey fell below the rate of GIA at 1100-1700 CE

491 indicating that other processes were causing a sea-level fall. As temperatures rose after 1700 CE, RSL

492 rise in Connecticut and New Jersey once again exceeded GIA. This pattern and magnitude of Little Ice

493 Age sea-level change likely resulted from the combined and simultaneous effects of cooling temperature

494 (globally and in North America) and a weakening Gulf Stream. Further research (including additional

495 sea-level records) is needed to distinguish and quantify the driving mechanisms of regional sea-level

496 change prior to the $19^{\text {th }}$ century.

498 6. Conclusions

499 We produced a compaction-free Common Era RSL reconstruction using salt-marsh sediment that 500 accumulated directly on top of bedrock at East River Marsh, Connecticut. This sediment was exposed by 501 excavating a trench and sampled to produce a suite of laterally and vertically ordered samples that 502 preserve a record of salt-marsh ecosystems transgressing the evenly sloped bedrock outcrop in response to 
RSL rise. Paleomarsh elevation was reconstructed with a transfer function trained on a regional-scale

504 dataset of modern foraminifera and supported by bulk-sediment measurements of $\delta^{13} \mathrm{C}$. A Bchron

505 age-elevation model was constructed from radiocarbon dates and pollution markers of known age. The

506 resulting 2200 year RSL reconstruction was combined with regional tide-gauge measurements and

507 analyzed using an error-in-variables integrated Gaussian process model to quantify persistent Common

508 Era sea-level trends with full consideration of uncertainty and the temporal distribution of data. After

509 removing an estimated rate of glacio-isostatic adjustment, the compaction-free sea-level reconstruction

510 shows a rise of $\sim 0.18 \mathrm{~mm} / \mathrm{yr}$ at $\sim 600-1000 \mathrm{CE}$ and a minimum rate of change $(-0.42 \mathrm{~mm} / \mathrm{yr})$ at $\sim 1400 \mathrm{CE}$.

511 The current rate of rise $(2.38 \mathrm{~mm} / \mathrm{yr})$ is the fastest century-scale rise of the last 2200 years and began at

512 1850-1886 CE, likely in response to global sea-level change. Prior to $1800 \mathrm{CE}$ sea-level trends in

513 Connecticut were similar to those in New Jersey, but dissimilar to those in Florida suggesting that

514 regional-scale processes (specifically ocean dynamics) were the primary driver of sea-level change.

515 Comparison with existing and reanalyzed RSL reconstructions at East River Marsh indicates that

516 sediment compaction is not a major driver of RSL trends reconstructed using cores of salt-marsh

517 sediment.

519 Acknowledgments

520 NOAA award NA11OAR4310101 and NSF grants EAR-1052848, EAR-0951686, and OCE-1154978 to

521 BPH, JPD, ADH, and ACK supported this work. We thank Alex Wright and Orson van de Plassche for

522 sharing their compilation of modern Connecticut foraminifera and understanding of Connecticut salt

523 marshes. Christopher Maio, Richard Sullivan, Jim Cedeberg, Emmy Tsang, and Alan Nelson provided

524 much-needed help in the field. Gabe Benoit and Helmut Ernstberger provided access to the DMA- 80 and

525 gamma counter. Vane publishes with the permission of the Director of the British Geological Survey. We

526 thank Rosemarie Drummond and Dick Peltier for providing GIA predictions and Robin Edwards and two 
527 anonymous reviewers for their helpful comments and suggestions. This is a contribution to PALSEA2 528 and IGCP Project 588 "Preparing for Coastal Change". 
Table 1: Radiocarbon ages from the East River Marsh trench

\begin{tabular}{|c|l|c|c|c|l|}
\hline $\begin{array}{c}\text { Elevation } \\
\text { (cm below } \\
\text { trench top) }\end{array}$ & ID & ${ }^{\mathbf{1 4}} \mathbf{C}$ Age & $\begin{array}{c}\mathbf{1 4}^{\mathbf{4}} \mathbf{C} \text { Age } \\
\text { Error }\end{array}$ & $\begin{array}{c}\boldsymbol{\delta}^{\mathbf{1 3}} \mathbf{C} \\
\mathbf{( \% )}, \mathbf{V P D B})\end{array}$ & Description \\
\hline 56 & OS-88674 & 175 & 30 & -15.20 & Distichlis spicata rhizome \\
\hline 66 & OS-86561 & 345 & 25 & -13.25 & Distichlis spicata rhizome \\
\hline 78 & OS-86562 & 550 & 30 & -12.81 & Distichlis spicata rhizome \\
\hline 90 & OS-89141 & 835 & 25 & -14.52 & Distichlis spicata rhizome \\
\hline 111 & OS-86567 & 1080 & 30 & -26.59 & Unidentified woody rhizome \\
\hline 146 & OS-86616 & 1300 & 25 & -16.23 & Distichlis spicata rhizome \\
\hline 156 & OS-86560 & 1490 & 25 & -13.28 & Distichlis spicata rhizome \\
\hline 158 & OS-89764 & 1490 & 30 & -14.56 & Distichlis spicata rhizome and bulb \\
\hline 165 & OS-89059 & 1570 & 25 & -14.03 & Distichlis spicata rhizome \\
\hline 184 & OS-88962 & 1790 & 25 & -24.89 & Piece of wood \\
\hline 195 & OS-86563 & 1830 & 30 & -26.33 & Unidentified woody rhizome \\
\hline 207 & OS-88656 & 1940 & 30 & -23.26 & Piece of wood \\
\hline 214 & OS-86550 & 2050 & 25 & -24.31 & Unidentified woody rhizome \\
\hline 224 & OS-88615 & 2050 & 45 & -26.03 & Piece of wood \\
\hline 231 & OS-88616 & 2080 & 40 & -24.36 & Piece of wood \\
\hline
\end{tabular}

531 Radiocarbon ages reported by the National Ocean Sciences Accelerator Mass Spectrometry facility for 532 samples in the East River Marsh trench. Reported $\delta^{13} \mathrm{C}$ values are from an aliquot of $\mathrm{CO}_{2}$ collected during 533 sample combustion. 


\section{Figure Captions}

535 Figure 1: (A) Location of East River Marsh (red circle) on the Long Island Sound coast of Connecticut. 536 Transects of modern (surface) foraminifera were collected from 12 new sites including East River Marsh

537 (\# 5-16) and combined with published datasets (\# 1-4) to generate a training set of 254 samples. NOAA

538 tide-gauge locations are represented by labelled (A-E) blue circles. Inset shows the location of other

539 high-resolution reconstructions of Common Era sea level from the U.S. Atlantic coast. (B, C) Location of 540 the trench and modern transects sampled at East River Marsh. The approximate location of three cores 541 used to reconstruct relative sea level by Nydick et al. (1995) are represented by open circles and labeled 542 using the abbreviations provided in the original publication.

Figure 2: (A) Profile of the trench excavated at East River Marsh. The bedrock-sediment contact (red

544 line) was sampled and used to reconstruct relative sea level. The high salt-marsh floral zone is vegetated

545 by Distichlis spicata and Spartina patens. The highest salt-marsh floral zone is vegetated by Iva

546 fructescens and Phragmites australis. NAVD88 = North American Vertical Datum of 1988. (B)

547 Schematic of trench sampling (not drawn to scale). In the field, the trench profile was segmented into

548 blocks (A-C) at changes in bedrock slope. All blocks were positioned in a co-ordinate system of depth

549 and distance by surveying the four bottom corners that were in contact with the bedrock. The origin for

550 this co-ordinate system was the trench top (panel A). The blocks (with a height of $\sim 15 \mathrm{~cm}$ ) were sampled,

551 wrapped in plastic with their orientation labeled and returned to the laboratory for sub-sampling.

552 Individual blocks were cut into sub samples (S1-S3) that each represented a depth change ( $\Delta$ depth) of 1

$553 \mathrm{~cm}$ by assuming that the measured slope of the bedrock ( $\Delta$ distance / $\Delta$ depth) was constant for each block.

554 Sample thickness was $1 \mathrm{~cm}$ and a mat of fine roots $(<2 \mathrm{~mm}$ thick) was removed from the bottom of the

555 samples where necessary and discarded following inspection. All analysis (radiocarbon and pollution

556 dating, $\delta^{13} \mathrm{C}$ measurements, and counts of foraminifera) was conducted on samples produced using this

557 approach. All samples were from the unit of amorphous, black organic with sand unit. (C) Photograph of

558 sampling sediment blocks in the field by cutting the trench wall to leave an over-sized step that 
segmented into blocks at changes in bedrock slope. (D) Photograph from the excavated trench showing the contact between the granitic bedrock and overlying accumulation of salt-marsh sediment. The black amorphous organic unit is overlain by brown organic mud. The height of the white scale bar is approximately $5 \mathrm{~cm}$.

Figure 3: (A) Relative abundance of the six most common species of foraminifera from samples in the East River Marsh trench. Am = Arenoparrella mexicana, $\mathrm{Tc}=$ Tiphotrocha comprimata, $\mathrm{Mp}=$ Miliammina petila. (B) Dissimilarity between trench samples and their closest analogue in the modern training set measured using the Bray Curtis distance metric. Symbol colors denote the site where the closest analog was located $. \mathrm{DB}=$ Double Beach, $\mathrm{ERM}=$ East River Marsh, $\mathrm{HM}=$ Hammonasset River Marsh, MK = Meunketesuk, PAT = Pattagansett River Marsh, SWD = Sherwood Island State Park. Samples exceeding the $20^{\text {th }}$ percentile of dissimilarity measured in modern samples were deemed to lack an adequate modern analog and were excluded from the reconstruction. (C) Paleomarsh elevation (PME) reconstructed using the weighted averaging transfer function. Circles represent mid points and grey error bars are the sample-specific uncertainty estimated by bootstrapping. Vertical dashed lines mark the elevation of mean high water (MHW), mean higher high water (MHHW), and highest astronomical tide (HAT). (D) Measured $\delta^{13} \mathrm{C}$ values from samples of bulk trench sediment. Left shaded grey area denotes samples more depleted than $-22 \%$ that are typical of salt-marsh environments above MHHW in mid-Atlantic and New England salt marshes, Righted shaded area denotes samples less depleted than-18.9 \%o that are typical of salt-marsh environments below MHHW in mid-Atlantic and New England salt marshes. The dashed vertical line at $-24.5 \%$ is the reported value for bulk sediment sample from a salt-marsh to upland transition in the Great Marshes of Massachusetts (Middleburg et al., 1997).

Figure 4: Down-core profiles of elemental abundances and isotopes used to recognize historical pollution markers. The age (year CE) and depth (with uncertainty) of each marker are listed and the grey shading denotes vertical uncertainty assigned to each chronohorizon for inclusion in the Bchron age-depth model. Analytical uncertainties are smaller than symbols used. 
Figure 5: Age-depth model developed for the East River Marsh trench. The shaded blue envelope is the $95 \%$ credible interval. Calibrated radiocarbon ages are the $2 \sigma$ range between the youngest and oldest possible ages and do not represent the probability distribution associated with ages within the range. Inset 587 shows detailed chronology for the last $\sim 200$ years.

588 Figure 6: (A) Annual tide-gauge measurements from seven locations in Long Island Sound expressed 589 relative to the 1980-1989 CE average. This reference period was used because the Port Jefferson 590 instrument ceased recording in 1990 CE. (B) Relative sea level reconstructed from the East River Marsh 591 trench. Each box represents a single datapoint with vertical and temporal uncertainty from the transfer 592 function and age-depth model respectively. The average tide-gauge record is expressed with respect to the 5932013 CE average to ensure that it can be compared directly to the RSL reconstruction. (C) Errors-In594 Variables Integrated Gaussian Process (EIV-IGP) fitted to the combined relative sea-level data from the 595 East River proxy reconstruction and the Long Island Sound averaged tide-gauge record. (D) Rate of 596 relative sea-level change estimated by the EIV-IGP model.

597 Figure 7: Reanalysis of the three cores (GD, GK, and GA, distinguished by color) used by Nydick et al. 598 (1995) to reconstructed relative sea level at East River Marsh (ERM) and West River Marsh. The 599 abundance of the three most common species of foraminifera reported by Nydick et al. (1995) are shown 600 in the top row of panels. Application of the Long Island Sound transfer function to these assemblages 601 reconstructed paleomarsh elevation (PME). Simplified core lithology is modified after Nydick et al. 602 (1995). An age-depth model was generated for each core using the radiocarbon ages and pollution marker 603 reported in the original study (middle row of panels). This reanalysis generated a relative sea level (RSL) 604 reconstruction for each core (lower row of panels) that followed a similar approach to the reconstruction 605 from the East River trench to allow direct and fair comparison among records. The reconstructions from 606 each core were analyzed by the error-in-variables integrated Gaussian process (EIV-IGP) model. The 607 trench reconstruction is also represented by results from the EIV-IGP model.. 
608 Figure 8: Common Era sea-level change on the U.S. Atlantic coast. Reconstructions are organized by 609 latitude from north (A) to south (D). Each reconstruction was analyzed using the Errors-in-Variables

610 Integrated Gaussian Process (EIV-IGP) model to ensure fair comparison among records. Left-side panels

611 are sea-level reconstructions after removing an estimated rate of glacio-isostatic adjustment (listed in

612 panel title). Labeled arrows indicate the timing of the primary change in the rate of sea-level estimated

613 using change point regression by applying the same model to all data sets. Right-side panels show

614 estimated rates of sea-level change after detrending. Scales are standardized within each column of panels

615 for comparability among records.

616 Figure 9: Change point analysis of global mean sea level estimated from a compilation of global tide 617 gauges. Annual estimates of global mean sea level are represented by boxes that incorporate vertical 618 uncertainties reported by Jevrejeva et al. (2008) and a temporal uncertainty of \pm 0.5 years. The mean and $61995 \%$ credible interval of the change point regression are presented as a solid line and shaded envelope 620 respectively. The timing of two change points (95\% credible interval) are shown by vertical shaded areas.

621 The linear rate of global mean sea level rise for periods defined by the change points are listed (95\%

622 credible interval). Labeled green bars indicate the timing of primary change points (95\% credible interval) 623 identified in proxy sea-level reconstructions from the U.S. Atlantic coast; the shared interval is 1865-1873

624 CE. 


\section{References}

661

662

663

664

665

666

667

668

669

670

671

672

673

Balco, G., Briner, J., Finkel, R.C., Rayburn, J.A., Ridge, J.C., Schaefer, J.M., 2009. Regional beryllium10 production rate calibration for late-glacial northeastern North America. Quaternary Geochronology 4, 93-107.

Barlow, N.L.M., Long, A.J., Saher, M.H., Gehrels, W.R., Garnett, M.H., Scaife, R.G., 2014. Salt-marsh reconstructions of relative sea-level change in the North Atlantic during the last 2000 years. Quaternary Science Reviews 99, 1-16.

Bloom, A.L., 1964. Peat accumulation and compaction in Connecticut coastal marsh. Journal of Sedimentary Research 34, 599-603.

Brain, M., Kemp, A.C., Horton, B.P., Culver, S.J., Parnell, A.C., Cahill, N., 2015. Quantifying the contribution of sediment compaction to late Holocene salt-marsh sea-level reconstructions, North Carolina, USA. Quaternary Research 83, 41-51.

Brain, M.J., Long, A.J., Woodroffe, S.A., Petley, D.N., Milledge, D.G., Parnell, A.C., 2012. Modelling the effects of sediment compaction on salt marsh reconstructions of recent sea-level rise. Earth and Planetary Science Letters 345-348, 180-193.

Cahill, N., Kemp, A.C., Horton, B.P., Parnell, A.C., 2015. Modeling sea-level change using errors-invariables intergrated Gaussian processes. Annals of Applied Statistics 9, 547-571.

Chmura, G.L., Aharon, P., 1995. Stable carbon isotope signatures of sedimentary carbon in coastal wetlands as indicators of salinity regime. Journal of Coastal Research 11, 124-135.

Church, J.A., Clark, P.U., Cazenave, A., Gregory, J.M., Jevrejeva, S., Levermann, A., Merrifield, M.A., Milne, G.A., Nerem, R.S., Nunn, P.D., Payne, A.J., Pfeffer, W.T., Stammer, D., Unnikrishnan, A.S., 2013. Sea-level change, in: Stocker, T.F., D. Qin, D., Plattner, G.K., Tignor, M., Allen, S.K., Boschung, J., Nauels, A., Xia, Y., Bex, V., Midgley, P.M. (Eds.), Climate Change 2013: The Physical Science Basis. Contribution of Working Group I to the Fifth Assessment Report of the Intergovernmental Panel on Climate Change. Cambridge University Press, pp. 1137-1216.

Church, J.A., White, N.J., 2006. A $20^{\text {th }}$ century acceleration in global sea-level rise. Geophysical

Research Letters 33, L01602.

Church, J.A., White, N.J., 2011. Sea-level rise from the late 19 th to the early 21 st century. Surveys in Geophysics 32, 585-602.

Consortium, P.k., 2013. Continental-scale temperature variability during the past two millennia. Nature Geoscience 6, 339-346.

Dey, D., Ghosh, S.K., Mallick, B.K., 2000. Generalized linear models: A Bayesian perspective. CRC Press.

Donnelly, J.P., Cleary, P., Newby, P., Ettinger, R., 2004. Coupling instrumental and geological records of sea-level change: evidence from southern New England of an increase in the rate of sea-level rise in the late 19th century. Geophysical Research Letters 31, L05203.

Edwards, R.J., Wright, A.J., van de Plassche, O., 2004. Surface distributions of salt-marsh foraminifera from Connecticut, USA: modern analogues for high-resolution sea level studies. Marine Micropaleontology 51, 1-21.

Engelhart, S.E., Horton, B.P., Douglas, B.C., Peltier, W.R., Tornqvist, T.E., 2009. Spatial variability of late Holocene and 20th century sea-level rise along the Atlantic coast of the United States. Geology 37, 1115-1118.

Engelhart, S.E., Peltier, W.R., Horton, B.P., 2011. Holocene relative sea-level changes and glacial isostatic adjustment of the U.S. Atlantic coast. Geology 39, 751-754.

Ezer, T., Atkinson, L.P., Corlett, W.B., Blanco, J.L., 2013. Gulf Stream's induced sea level rise and variability along the U.S. mid-Atlantic coast. Journal of Geophysical Research: Oceans 118, 685-697. Gehrels, W.R., van de Plassche, O., 1999. The use of Jadammina macrescens (Brady) and Balticammina pseudomacrescens Brönnimann, Lutze and Whittaker (Protozoa: Foraminiferida) as sea-level indicators. Palaeogeography, Palaeoclimatology, Palaeoecology 149, 89-101. 
Gobeil, C., Tessier, A., Couture, R.-M., 2013. Upper Mississippi Pb as a mid-1800s chronostratigraphic marker in sediments from seasonally anoxic lakes in Eastern Canada. Geochimica et Cosmochimica Acta 113, 125-135. Haslett, J., Parnell, A., 2008. A simple monotone process with application to radiocarbon-dated depth chronologies. Journal of the Royal Statistical Society: Series C (Applied Statistics) 57, 399-418. Hay, C., Mitrovica, J.X., Gomez, N., Creveling, J.R., Austermann, J., E. Kopp, R., 2014. The sea-level fingerprints of ice-sheet collapse during interglacial periods. Quaternary Science Reviews 87, 60-69. Hay, C., Morrow, E., Kopp, R.E., Mitrovica, J.X., 2015. Probabilistic reanalysis of twentieth-century sealevel rise. Nature.

Holsclaw, T., Sansó, B., Lee, H.K., Heitmann, K., Habib, S., Higdon, D., Alam, U., 2013. Gaussian process modeling of derivative curves. Technometrics 55, 57-67.

Horton, B.P., 1999. The distribution of contemporary intertidal foraminifera at Cowpen Marsh, Tees Estuary, UK: implications for studies of Holocene sea-level changes. Palaeogeography Palaeoclimatology Palaeoecology 149, 127-149.

Jevrejeva, S., Moore, J.C., Grinsted, A., Woodworth, P.L., 2008. Recent global sea level acceleration started over 200 years ago? Geophysical Research Letters 35, L08715.

Johnson, B.J., Moore, K.A., Lehmann, C., Bohlen, C., Brown, T.A., 2007. Middle to late Holocene fluctuations of $\mathrm{C}_{3}$ and $\mathrm{C}_{4}$ vegetation in a Northern New England Salt Marsh, Sprague Marsh, Phippsburg Maine. Organic Geochemistry 38, 394-403.

Juggins, S., Birks, H.J.B., 2012. Quantiative environmental reconstructions from biological data, in: Birks, H.J.B., Lotter, A.F., Juggins, S., Smol, J.P. (Eds.), Tracking environmental change using lake sediments: Data handling and numerical techniques. Springer, pp. 431-494.

Kemp, A.C., Bernhardt, C.E., Horton, B.P., Vane, C.H., Peltier, W.R., Hawkes, A.D., Donnelly, J.P., Parnell, A.C., Cahill, N., 2014. Late Holocene sea- and land-level change on the U.S. southeastern Atlantic coast. Marine Geology 357, 90-100.

Kemp, A.C., Horton, B., Donnelly, J.P., Mann, M.E., Vermeer, M., Rahmstorf, S., 2011. Climate related sea-level variations over the past two millennia. Proceedings of the National Academy of Sciences 108, 11017-11022.

Kemp, A.C., Horton, B.P., Vane, C.H., Corbett, D.R., Bernhardt, C.E., Engelhart, S.E., Anisfeld, S.C., Parnell, A.C., Cahill, N., 2013a. Sea-level change during the last 2500 years in New Jersey, USA. Quaternary Science Reviews 81, 90-104.

Kemp, A.C., Sommerfield, C.K., Vane, C.H., Horton, B.P., Chenery, S.R., Anisfeld, S.C., Nikitina, D., 2012a. Use of lead isotopes for developing chronologies in recent salt-marsh sediments. Quaternary Geochronology 12, 40-49.

Kemp, A.C., Telford, R.J., Horton, B.P., Anisfeld, S.C., Sommerfield, C.K., 2013b. Reconstructing Holocene sea-level using salt-marsh foraminifera and transfer functions: lessons from New Jersey, USA. Journal of Quaternary Science 28, 617-629.

Kemp, A.C., Vane, C.H., Horton, B.P., Engelhart, S.E., Nikitina, D., 2012b. Application of stable carbon isotopes for reconstructing salt-marsh floral zones and relative sea level, New Jersey, USA. Journal of Quaternary Science 27, 404-414.

Kienert, H., Rahmstorf, S., 2012. On the relation between Meridional Overturning Circulation and sealevel gradients in the Atlantic. Earth System Dynamics 3, 109-120.

Lima, A.L., Bergquist, B.A., Boyle, E.A., Reuer, M.K., Dudas, F.O., Reddy, C.M., Eglinton, T.I., 2005. High-resolution historical records from Pettaquamscutt River basin sediments: 2. Pb isotopes reveal a potential new stratigraphic marker. Geochimica et Cosmochimica Acta 69, 1813-1824.

Long, A.J., Barlow, N.L.M., Gehrels, W.R., Saher, M.H., Woodworth, P.L., Scaife, R.G., Brain, M.J., Cahill, N., 2014. Contrasting records of sea-level change in the eastern and western North Atlantic during the last 300 years. Earth and Planetary Science Letters 388, 110-122.

Lund, D.C., Lynch-Stieglitz, J., Curry, W.B., 2006. Gulf Stream density structure and transport during the last millennium. Nature 444, 601-604. 
Mann, M.E., Zhang, Z., Hughes, M.K., Bradley, R.S., Miller, S.K., Rutherford, S., Ni, F., 2008. Proxybased reconstructions of hemispheric and global surface temperature variations over the past two millennia. Proceedings of the National Academy of Sciences 105, 13252-13257.

Masson-Delmonte, V., Schulz, M., Abe-Ouchi, A., Beer, J., Ganopolski, A., González Rouco, J.F., Jansen, E., Lambeck, K., Luterbacher, J., Naish, T., Osborn, T., Otto-Bliesner, B., Quinn, T., Ramesh, R., Rojas, M., Shao, X., Timmermann, A., 2013. Information from Paleoclimate Archives, in: Stocker, T.F., D. Qin, D., Plattner, G.K., Tignor, M., Allen, S.K., Boschung, J., Nauels, A., Xia, Y., Bex, V., Midgley, P.M. (Eds.), Climate Change 2013: The Physical Science Basis. Contribution of Working Group I to the Fifth Assessment Report of the Intergovernmental Panel on Climate Change. Cambridge University Press, pp. 383-464.

McCarthy, G.D., Haigh, I.D., Hirschi, J.J.M., Grist, J.P., Smeed, D.A., 2015. Ocean impact on decadal Atlantic climate variability revealed by sea-level observations. Nature 521, 508-510.

Middleburg, J.J., Nieuwenhuize, J., Lubberts, R.K., van de Plassche, O., 1997. Organic carbon isotope systematics of coastal marshes. Estuarine Coastal and Shelf Science 45, 681-687.

Mitrovica, J.X., Tamisiea, M.E., Davis, J.L., Milne, G.A., 2001. Recent mass balance of polar ice sheets inferred from patterns of global sea-level change. Nature 409, 1026-1029.

Nydick, K.R., Bidwell, A.B., Thomas, E., Varekamp, J.C., 1995. A sea-level rise curve from Guilford, Connecticut, USA. Marine Geology 124, 137-159.

Parnell, A.C., Haslett, J., Allen, J.R.M., Buck, C.E., Huntley, B., 2008. A flexible approach to assessing synchroneity of past events using Bayesian reconstructions of sedimentation history. Quaternary Science Reviews 27, 1872-1885. Peltier, W.R., 1996. Global sea level rise and glacial isostatic adjustment: an analysis of data from the east coast of North America. Geophysical Research Letters 23, GL00848.

Peltier, W.R., Argus, D.F., Drummond, R., 2014. Space geodesy constrains ice-age terminal deglaciation: the ICE-6G_C (VM5a) model. Journal of Geophysical Research: Solid Earth. Institue of Technology Press.

Redfield, A.C., Rubin, M., 1962. The age of salt marsh peat and its relation to recent changes in sea level at Barnstable, Massachusetts. Proceedings of the National Academy of Sciences of the United States of America 48, 1728-1735.

Rowley, D.B., Forte, A.M., Moucha, R., Mitrovica, J.X., Simmons, N.A., Grand, S.P., 2013. Dynamic Topography Change of the Eastern United States Since 3 Million Years Ago. Science 340, 1560-1563. Scott, D.B., Medioli, F.S., 1978. Vertical zonations of marsh foraminifera as accurate indicators of former sea levels. Nature 272, 528-531.

Shennan, I., Horton, B., 2002. Holocene land-and sea-level changes in Great Britain. Journal of Quaternary Science 17, 511-526.

Shennan, I., Woodworth, P.L., 1992. A comparison of late Holocene and twentieth-century sea-level trends from the UK and North Sea region. Geophysical Journal International 109, 96-105.

Thomas, E., Varekamp, J., 1991. Paleo-environmental analysis of marsh sequences (Clinton, CT); evidence for punctuated sea-level rise during the latest Holocene. Journal of Coastal Research 11, 125158.

van de Plassche, O., 1991. Late Holocene sea-level fluctuations on the shore of Connecticut inferred from transgressive and regressive overlap boundaries in salt-marsh deposits. Journal of Coastal Research 11, 159-179.

van de Plassche, O., van der Borg, K., de Jong, A.F.M., 1998. Sea level-climate correlation during the past 1400 yr. Geology 26, 319-322.

Vane, C.H., Chenery, S.R., Harrison, I., Kim, A.W., Moss-Hayes, V., Jones, D.G., 2011. Chemical signatures of the Anthropocene in the Clyde estuary, UK: sediment-hosted Pb, 207/206Pb, total petroleum hydrocarbon, polyaromatic hydrocarbon and polychlorinated biphenyl pollution records. Philosophical Transactions of the Royal Society A: Mathematical, Physical and Engineering Sciences $369,1085-1111$. 
775 Varekamp, J., Kreulen, B., ten Brink, B.M., Mecray, E., 2003. Mercury contamination chronologies from 776 Connecticut wetlands and Long Island Sound sediments. Environmental Geology 43, 268-282.

777 Varekamp, J., Thomas, E., van de Plassche, O., 1992. Relative sea-level rise and climate change over the 778 last 1500 years. Terra Nova 4, 293-304.

779 Woodworth, P.L., Teferle, F.N., Bingley, R.M., Shennan, I., Williams, S.D.P., 2009. Trends in UK mean 780 sea level revisited. Geophysical Journal International 176, 19-30.

781 Wright, A.J., Edwards, R.J., van de Plassche, O., 2011. Reassessing transfer-function performance in sea782 level reconstruction based on benthic salt-marsh foraminifera from the Atlantic coast of NE North 783 America. Marine Micropaleontology 81, 43-62.

784 Yin, J., Goddard, P.B., 2013. Oceanic control of sea level rise patterns along the East coast of the United 785 States. Geophysical Research Letters 40, 5514-5520. 
FigureV

\section{Figure 1}
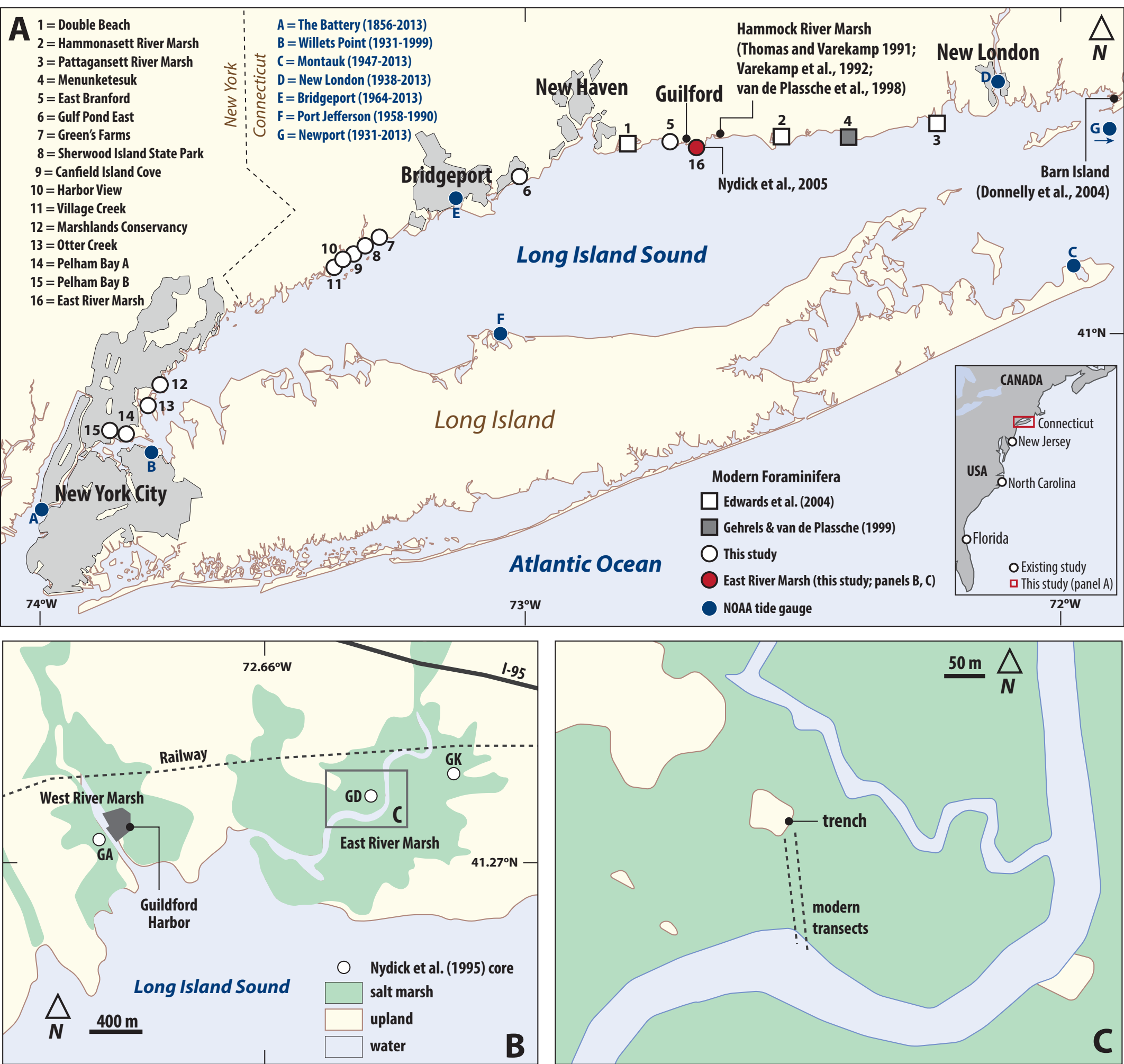

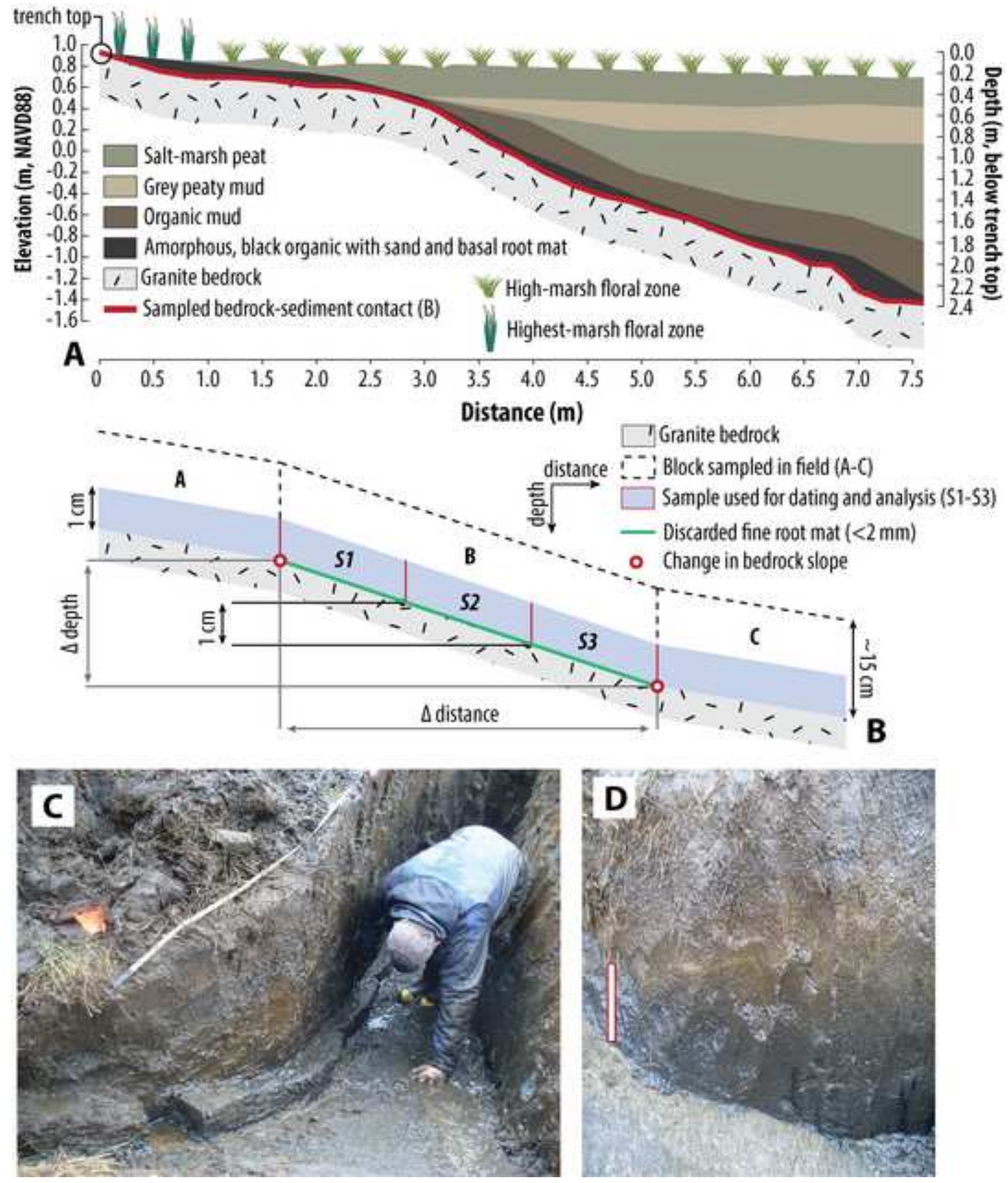
Figure 3
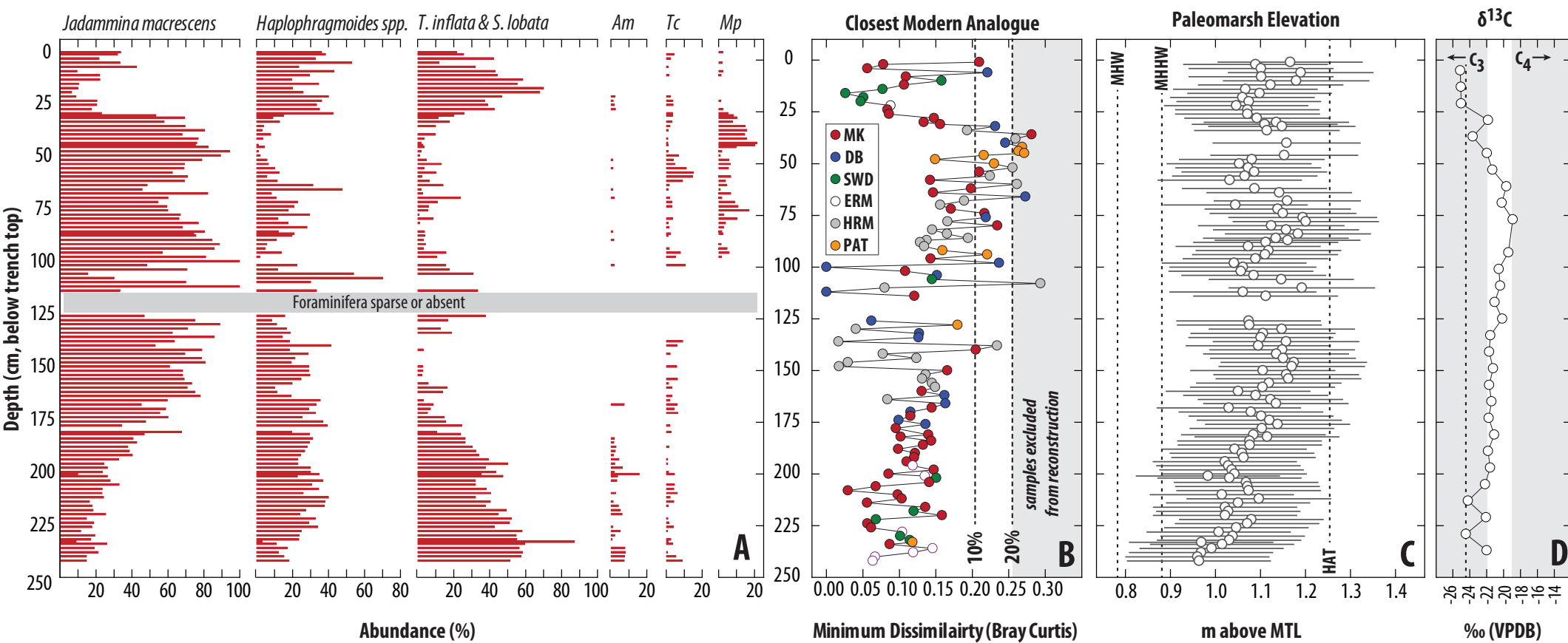
Figure 4

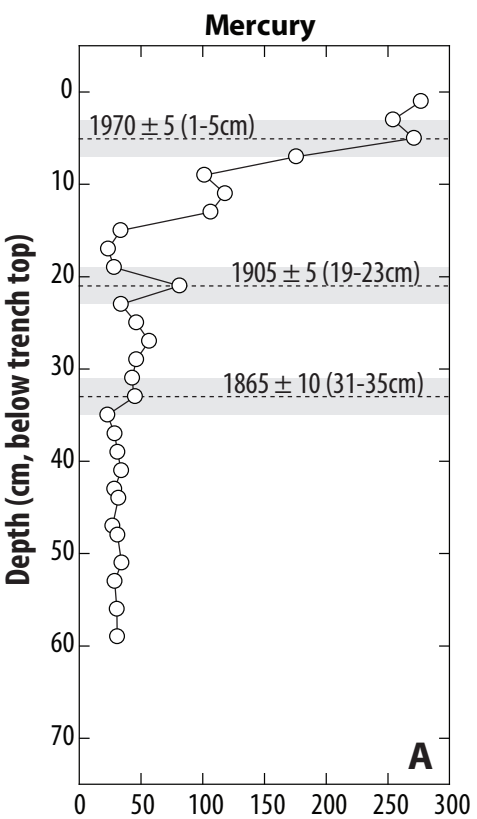

$\begin{array}{llllll}50 & 100 & 150 & 200 & 250 & 300\end{array}$ Concentration (ug/kg)
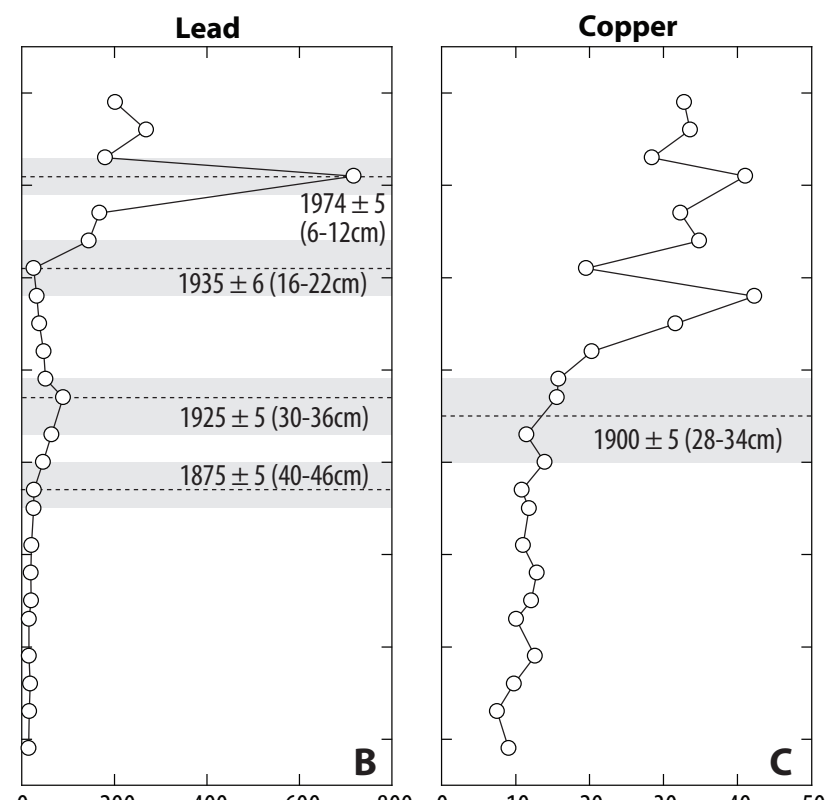

Concentration (mg/kg)

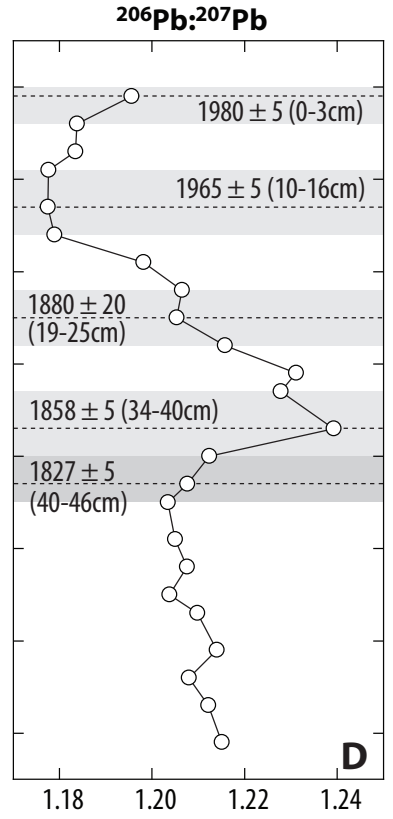

Concentration $(\mathrm{mg} / \mathrm{kg})$

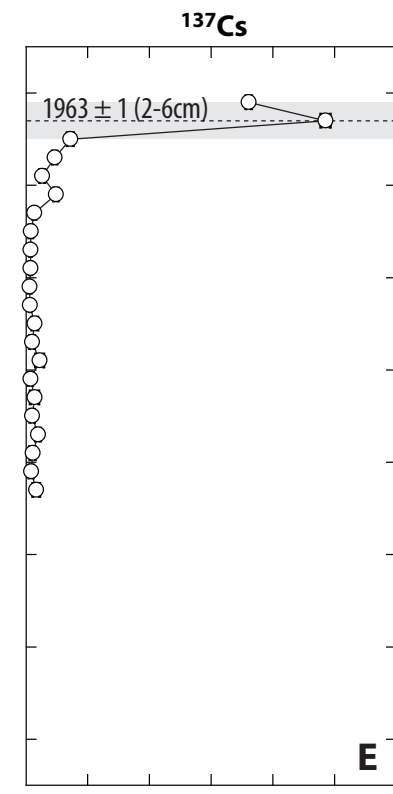

$\begin{array}{lllll}0.02 & 0.04 & 0.06 & 0.08 & 0.10\end{array}$ Activity (mBq/g) 


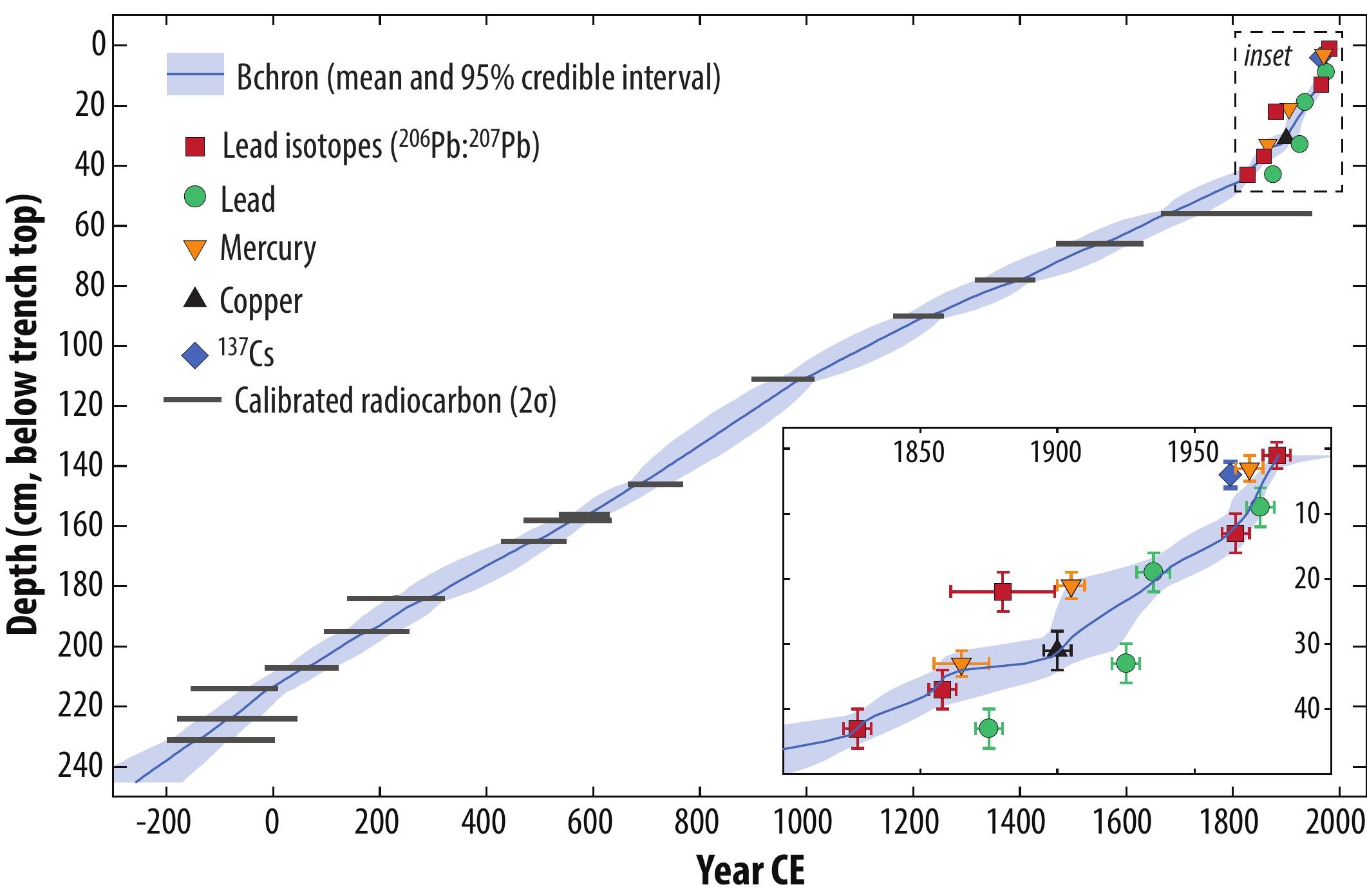


Salt-marsh peat Grey clayey peat
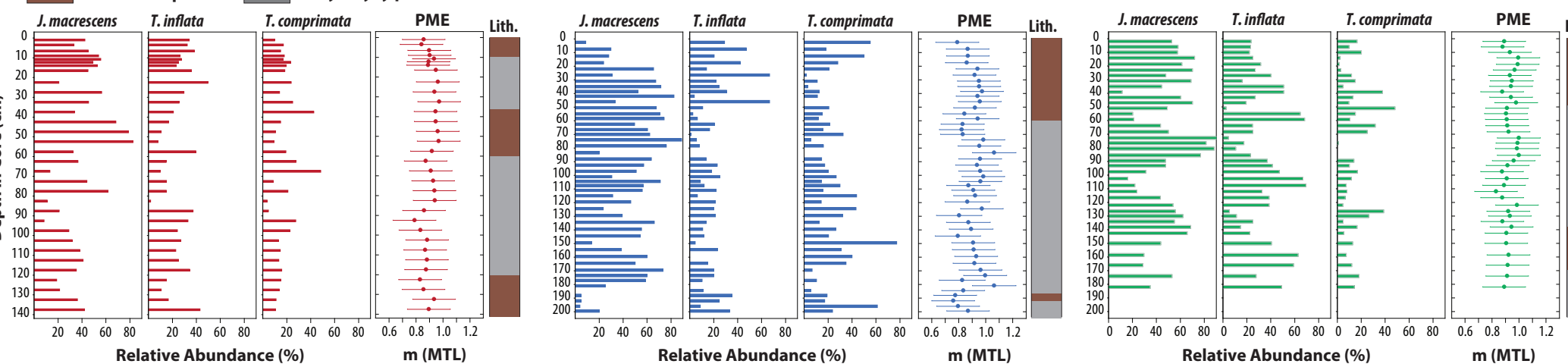

$\begin{array}{lllllllllllllllllll}0 & 20 & 40 & 60 & 80 & 0 & 20 & 40 & 60 & 80 & 0 & 20 & 40 & 60 & 80 & 0.6 & 0.8 & 1.0 & 1.2\end{array}$ Relative Abundance (\%) m (MTL)

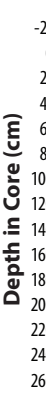
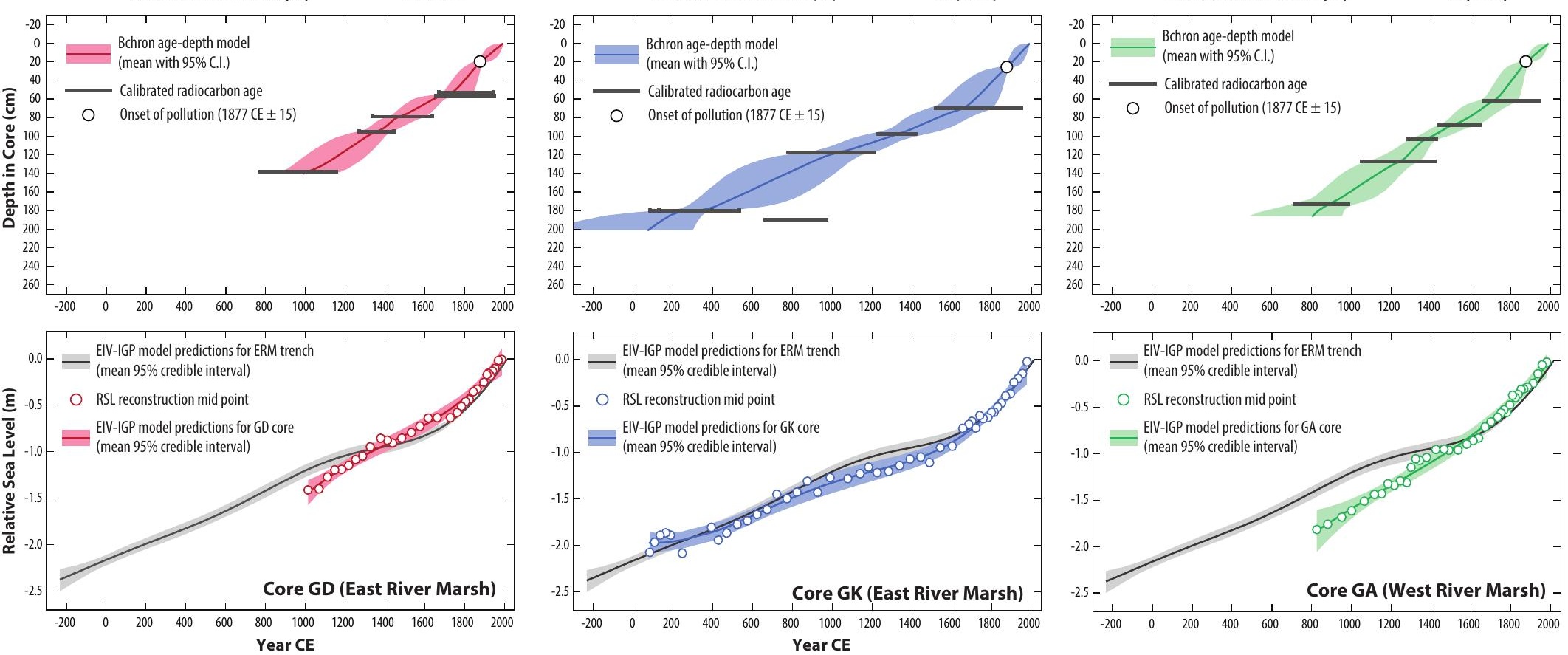


\section{Detrended Sea Level}
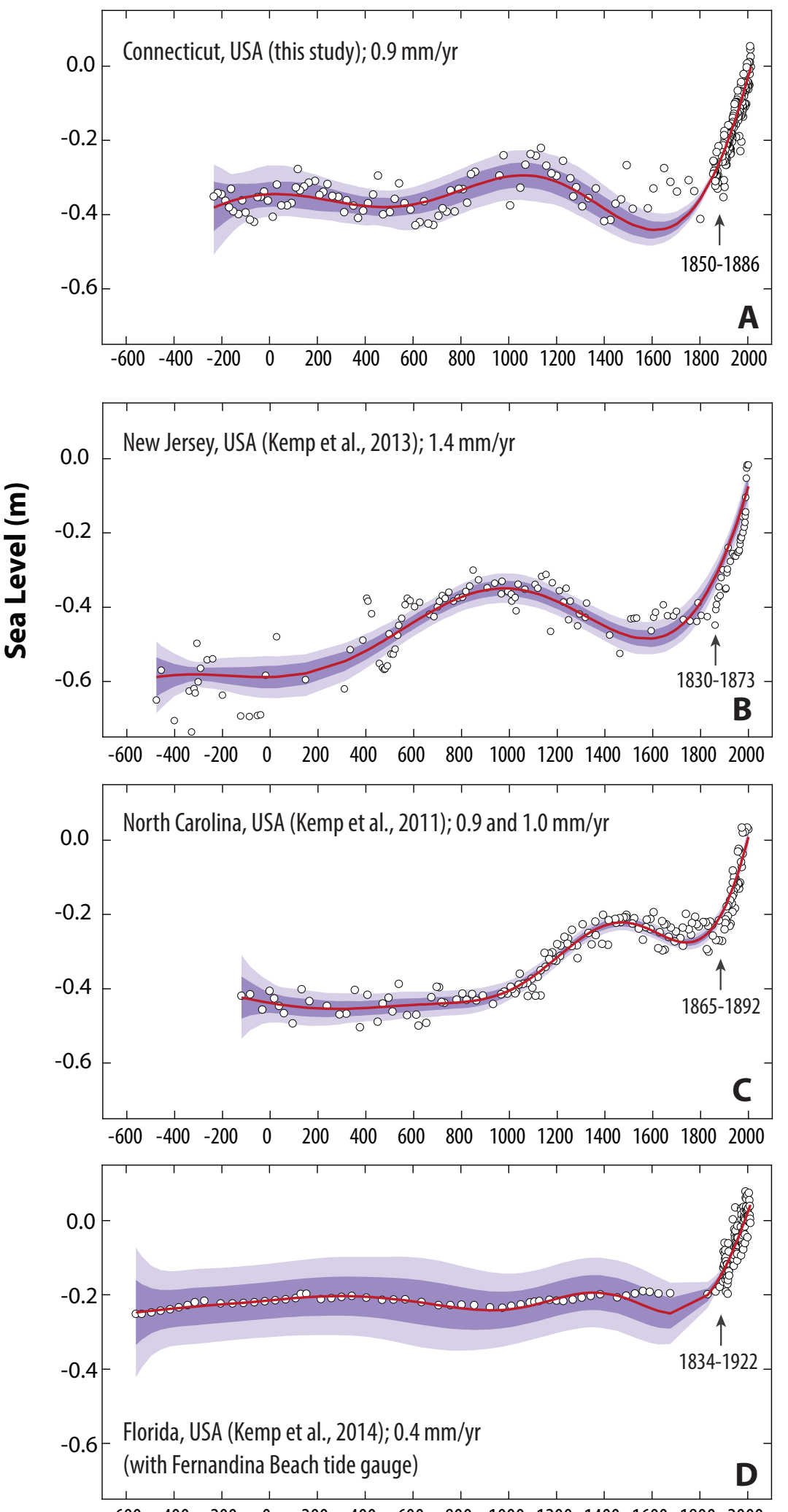
$\begin{array}{llllllllllllll}-600 & -400 & -200 & 0 & 200 & 400 & 600 & 800 & 1000 & 1200 & 1400 & 1600 & 1800 & 2000\end{array}$ Year CE

\section{Rate of Detrended Sea-Level Change}
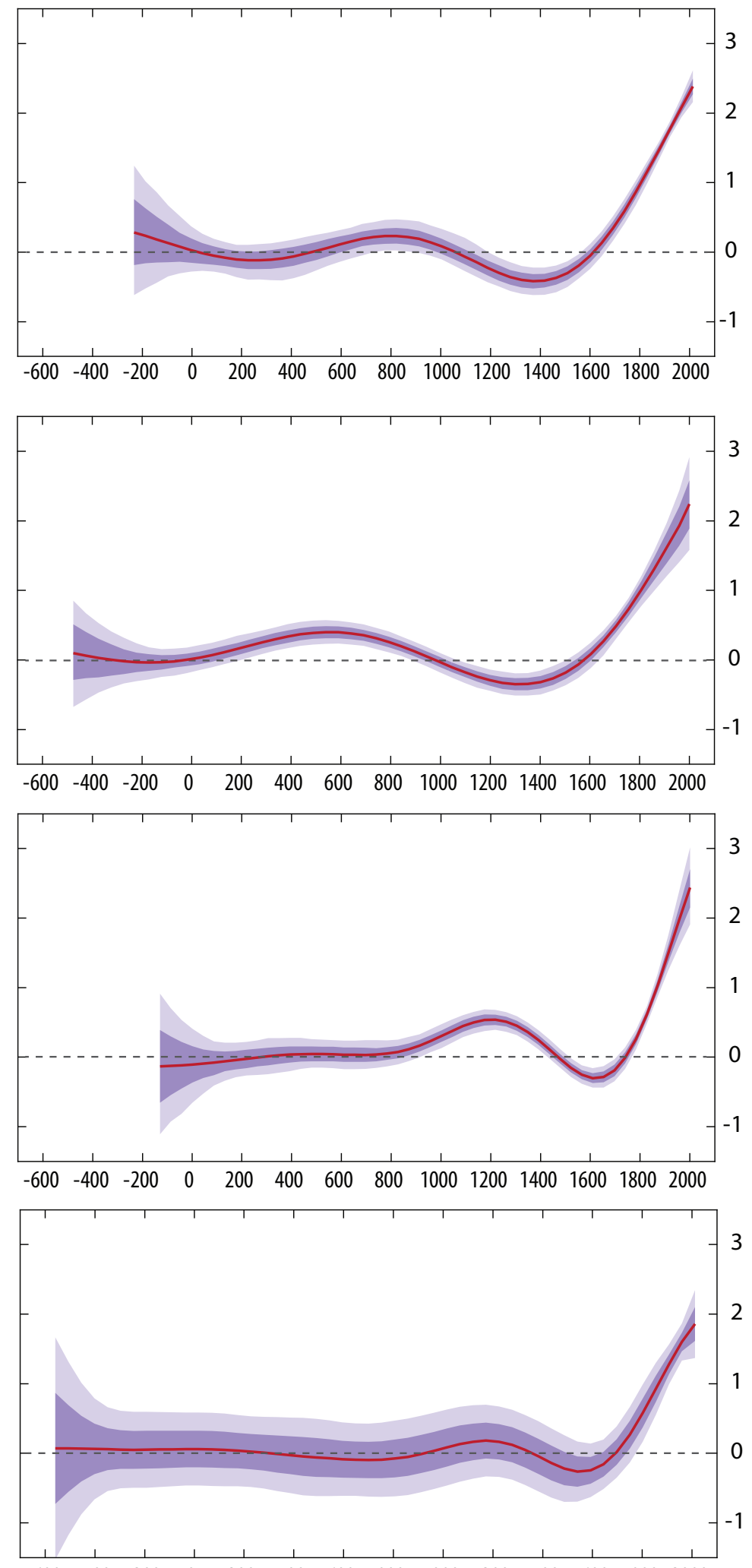

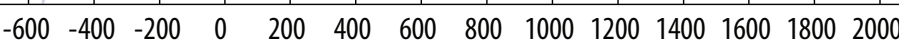

\section{Year CE}




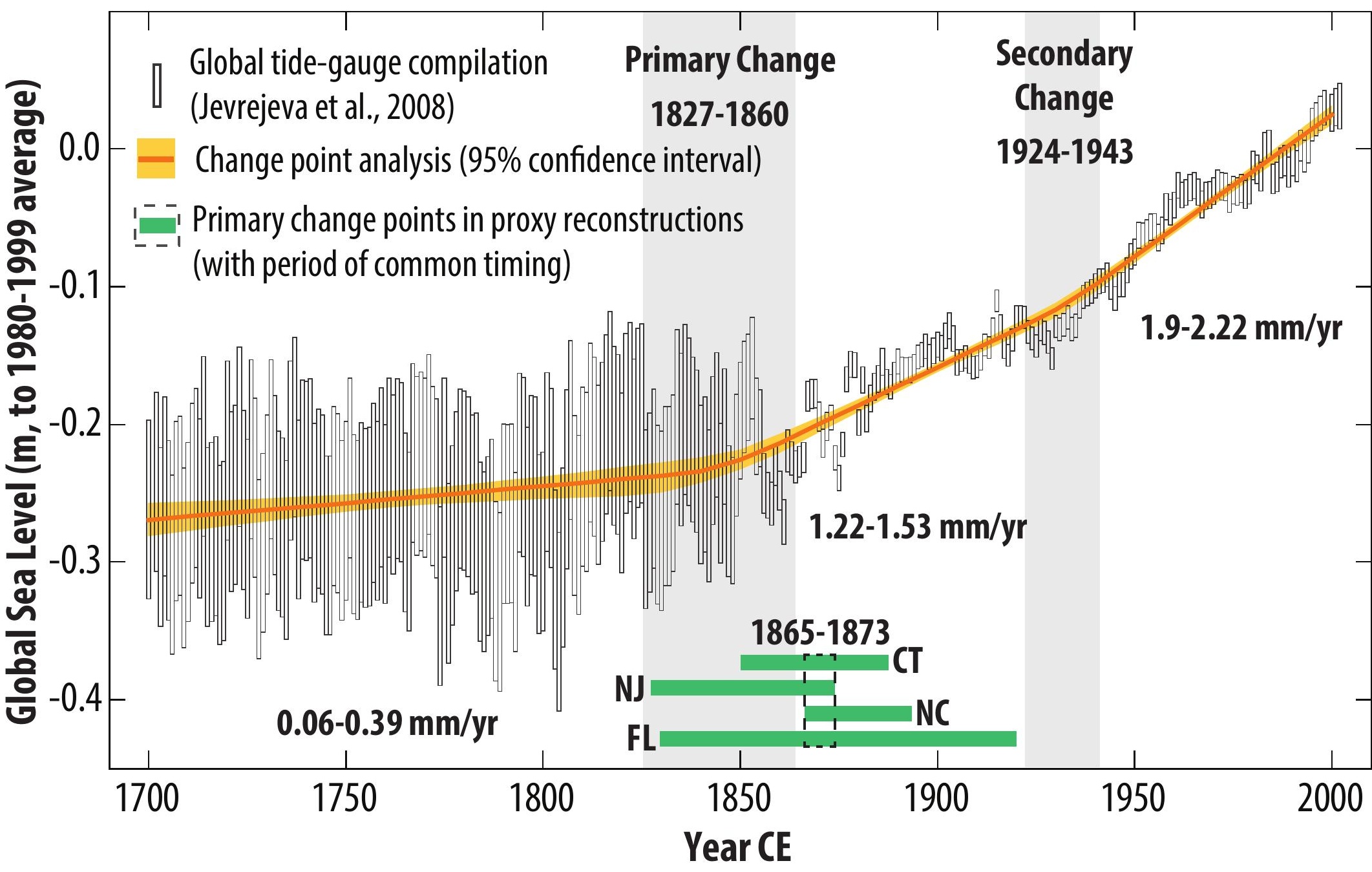

